\title{
Abundant Genetic Diversity and Extensive Differentiation among Geographic Populations of the Citrus Pathogen Diaporthe citri in Southern China
}

\author{
Tao Xiong ${ }^{1}$, Yating Zeng ${ }^{1}$, Wen Wang ${ }^{1}$, Pudong Li ${ }^{1}$, Yunpeng Gai ${ }^{1}$, Chen Jiao ${ }^{1}$, Zengrong Zhu ${ }^{1,2}$, \\ Jianping $X \mathrm{u}^{3, *}$ (D) and Hongye $\mathrm{Li}^{1,2, *}$
}

1 Ministry of Agricultural and Rural Affairs Key Laboratory of Molecular Biology of Crop Pathogens and Insect Pests, Institute of Biotechnology, Zhejiang University, Hangzhou 310058, China; 21816084@zju.edu.cn (T.X.); 21816172@zju.edu.cn (Y.Z.); 11916090@zju.edu.cn (W.W.); pdli@zju.edu.cn (P.L.); gaiy@zju.edu.cn (Y.G.); biochenjiao@zju.edu.cn (C.J.); zrzhu@zju.edu.cn (Z.Z.)

2 Hainan Institute, Zhejiang University, Sanya 572000, China

3 Department of Biology, McMaster University, Hamilton, ON L8S 4K1, Canada

* Correspondence: jpxu@mcmaster.ca (J.X.); hyli@zju.edu.cn (H.L.)

Citation: Xiong, T.; Zeng, Y.; Wang, W.; Li, P.; Gai, Y.; Jiao, C.; Zhu, Z.; Xu, J.; Li, H. Abundant Genetic Diversity and Extensive Differentiation among Geographic Populations of the Citrus Pathogen Diaporthe citri in Southern China. J. Fungi 2021, 7, 749. https:// doi.org/10.3390/jof7090749

Academic Editor: Philippe Silar

Received: 19 August 2021

Accepted: 9 September 2021

Published: 13 September 2021

Publisher's Note: MDPI stays neutral with regard to jurisdictional claims in published maps and institutional affiliations.

Copyright: (c) 2021 by the authors. Licensee MDPI, Basel, Switzerland. This article is an open access article distributed under the terms and conditions of the Creative Commons Attribution (CC BY) license (https:/ / creativecommons.org/licenses/by/ $4.0 /)$.

\begin{abstract}
The fungal pathogen Diaporthe citri is a major cause of diseases in citrus. One common disease is melanose, responsible for large economic losses to the citrus fruit industry. However, very little is known about the epidemiology and genetic structure of D. citri. In this study, we analyzed 339 isolates from leaves and fruits with melanose symptoms from five provinces in southern China at 14 polymorphic simple sequence repeat (SSR) loci and the mating type idiomorphs. The genetic variations were analyzed at three levels with separate samples: among provinces, among orchards within one county, and among trees within one orchard. The five provincial populations from Fujian, Zhejiang, Jiangxi, Hunan, and Guizhou were significantly differentiated, while limited differences were found among orchards from the same county or among trees from the same orchard. STRUCTURE analysis detected two genetic clusters in the total sample, with different provincial subpopulations showing different frequencies of isolates in these two clusters. Mantel analysis showed significant positive correlation between genetic and geographic distances, consistent with geographic separation as a significant barrier to gene flow in D. citri in China. High levels of genetic diversity were found within individual subpopulations at all three spatial scales of analyses. Interestingly, most subpopulations at all three spatial scales had the two mating types in similar frequencies and with alleles at the 14 SSR loci not significantly different from linkage equilibrium. Indeed, strains with different mating types and different multilocus genotypes were frequently isolated from the same leaves and fruits. The results indicate that sexual reproduction plays an important role in natural populations of $D$. citri in southern China and that its ascospores likely represent an important contributor to citrus disease.
\end{abstract}

Keywords: citrus melanose; simple sequence repeats; geographic differentiation; genetic clusters; mating type; linkage disequilibrium; sexual reproduction

\section{Introduction}

Diaporthe citri (anamorph Phomopis citri) is one of the most important pathogenic fungi on citrus. It induces melanose on the leaves, twigs, and fruits; stem-end rot of postharvest fruits; and gummosis and blight of shoots, perennial branches, and trunks of citrus. Among these diseases, melanose brings perhaps the most significant economic loss since it significantly reduces the marketability of citrus fruits [1-5]. This fungal pathogen is widespread in humid citrus-producing areas, except for California in the US and Europe $[5,6]$. All citrus species are susceptible to D. citri infection, with grapefruit and lemons being the most severely affected [5]. 
D. citri produces both sexual spores (ascospores) and asexual spores (conidia) on dead twigs and branches, but it is not known to sporulate on living tissues [7,8]. Several studies have reported perithecia, the sexual reproductive organ of $D$. citri, on decaying wood on the ground or on the dead branches on trees [7-9]. Once mature, ascospores could eject from perithecia, become airborne, and disseminate to new niches. However, perithecia are not commonly found in nature, suggesting ascospores may play a relatively minor role in the epidemiology of melanose. Instead, the asexual reproductive organs pycnidia are often observed abundantly on dead twigs, from which the conidia are often shown as slimy masses secreted from these twigs during the citrus growing season, especially after rainfall $[5,7,8]$. Conidia can spread by rain-splash to leaves, twigs, and fruits, causing shortdistance dispersals of this pathogen to other sites, either within the same tree canopy or to adjacent trees. Thus, the reproductive cycle of this fungus has been primarily considered as occurring on dead twigs and decaying woods, and with the living infected tissues playing a minor role in its reproduction in nature $[3,5,7,8]$.

The genus Diaporthe belongs to the order Diaporthales in class Sordariomycetes of the Ascomycota phylum. Species in Diaporthe usually have broad host ranges, with most species capable of infecting multiple plants [10-12]. Aside from D. citri, other species in Diaporthe can also cause diseases such as necrosis spots, diebacks, cankers, decay, or wilts on different plant hosts including cultivated crops, trees, and ornamental plants, which could lead to host tree deaths or significant economic losses. Examples of diseases caused by Diaporthe species on common crops include the soybean stem blight by Diaporthe phaseolorum; stem canker of sunflower by Diaporthe helianthi; leaf spot, swelling arm, and perennial cankers of grapevines by multiple Diaporthe species; and branch cankers and fruit stem-end rot of avocado by Diaporthe foeniculina and Diaporthe sterilis [6,11-15]. Although the importance of D. citri and other pathogens in the Diaporthe genus is well-recognized, our knowledge about their diversity, population genetics, reproduction strategies, and pathogenicity is very limited $[16,17]$. Knowledge on their population biology and mode of reproduction in nature can help us understand many issues, including the mechanisms of pathogenesis and host range, the development of fungicide resistance, and the effectiveness of phytosanitary measures. Such knowledge can facilitate the development of sustainable management strategies against this and other groups of plant fungal pathogens [18-20].

Recently, with the analyses and release of the genomic sequences of 12 species in the genus Diaporthe, including those of three isolates of D. citri (ZJUD2, ZJUD14, and Q7), the heterothallic mating system and the structures and DNA sequences of both mating types (MAT) were elucidated [21,22]. DNA sequence analyses revealed that each strain of D. citri contained only one mating type (MAT) idiomorph: strain ZJUD14 contained MAT1-1 and strains ZJUD2 and Q7 contained MAT1-2 [22]. These genome sequences allow us to develop genetic markers to explore the population structure, genetic diversity, and mating type distributions in natural populations of D. citri. Specifically, in this study, we aimed to analyze the patterns of genetic variation at three spatial scales: (i) at the provincial level among five provinces (Fujian, Zhejiang, Jiangxi, Hunan, and Guizhou) in southern China, (ii) among four orchards within one county in Hunan Province, and (iii) among five trees from a single orchard, also in Hunan. In total, we obtained 339 isolates and analyzed their genotypes at 14 newly developed polymorphic simple sequence repeat (SSR, microsatellites) markers. In addition, the mating type of each isolate was determined using a mating type-specific PCR. We hypothesize that geographic separation plays a major role in genetic relationships among subpopulations of $D$. citri. Specifically, we hypothesize that the five provincial populations of $D$. citri in southern China will be genetically differentiated, while relatively limited differences will be found among subpopulations of $D$. citri from different orchards within the same county and among samples from different trees within the same orchard. In addition, based on what has been reported before about the dominance of the asexual reproduction of $D$. citri in nature $[5,8,9]$, we hypothesize that there will be abundant evidence for asexual reproduction, including evidence for linkage disequilibrium, with multiple isolates sharing the same genotypes, especially among $D$. citri isolates from 
the same tree and the same orchard. Furthermore, based on the observed broad host range of $D$. citri [10-12], we hypothesize that there will be limited host tree-based and host organ-based population structure of this fungal pathogen. To test the third hypothesis, melanose-diseased samples from two host tree species from within the same county were analyzed. Similarly, melanose-diseased leaves and fruits from the same trees within a single orchard were sampled and analyzed. Together, these hypotheses were tested using a variety of samples and statistical and population genetic methods.

\section{Materials and Methods}

\subsection{Isolate Collection}

In total, 339 single-conidial isolates of $D$. citri were collected between June and September in 2019 from Citrus reticulata (Ponkan) and C. sinensis (navel orange) in 21 orchards in five provinces of southern China (Table 1). These samples were collected to address strain relationships and population genetic structures at three spatial levels, as described below.

Table 1. Information about population samples of Diaporthe citri collected from citrus orchards in southern and southeastern China in 2019 for this study.

\begin{tabular}{|c|c|c|c|c|c|c|}
\hline Populations & Source of Location & Longitude & Latitude & Host & $\begin{array}{c}\text { Designation of } \\
\text { Population }\end{array}$ & $\begin{array}{c}\text { Number of } \\
\text { Isolates }\end{array}$ \\
\hline \multirow{23}{*}{ Province } & Fujian & & & \multirow{5}{*}{ Citrus reticulata } & \multirow[t]{5}{*}{ FJ } & 24 \\
\hline & Shunchang A & $117.94^{\circ} \mathrm{E}$ & $27.12^{\circ} \mathrm{N}$ & & & 3 \\
\hline & Shunchang B & $117.90^{\circ} \mathrm{E}$ & $27.12^{\circ} \mathrm{N}$ & & & 1 \\
\hline & Songxi A & $117.89^{\circ} \mathrm{E}$ & $27.03^{\circ} \mathrm{N}$ & & & 1 \\
\hline & Songxi B & $116.41^{\circ} \mathrm{E}$ & $27.05^{\circ} \mathrm{N}$ & & & 19 \\
\hline & Guizhou & & & \multirow{4}{*}{ C. reticulata } & \multirow[t]{4}{*}{ GZ } & 30 \\
\hline & Congjiang A & $108.88^{\circ} \mathrm{E}$ & $25.67^{\circ} \mathrm{N}$ & & & 10 \\
\hline & Congjiang B & $108.82^{\circ} \mathrm{E}$ & $25.71^{\circ} \mathrm{N}$ & & & 9 \\
\hline & Congjiang C & $108.84^{\circ} \mathrm{E}$ & $25.71^{\circ} \mathrm{N}$ & & & 11 \\
\hline & Jiangxi & & & \multirow{5}{*}{ C. reticulata } & \multirow[t]{5}{*}{$\mathrm{JX}$} & 30 \\
\hline & Jingan A & $115.36^{\circ} \mathrm{E}$ & $28.85^{\circ} \mathrm{N}$ & & & 8 \\
\hline & Jingan B & $115.30^{\circ} \mathrm{E}$ & $28.85^{\circ} \mathrm{N}$ & & & 10 \\
\hline & Jingan C & $115.39^{\circ} \mathrm{E}$ & $28.81^{\circ} \mathrm{N}$ & & & 7 \\
\hline & Jingan D & $115.40^{\circ} \mathrm{E}$ & $28.82^{\circ} \mathrm{N}$ & & & 5 \\
\hline & Zhejiang & & & \multirow{6}{*}{ C. reticulata } & \multirow[t]{6}{*}{ ZJ } & 28 \\
\hline & Kecheng A & $118.82^{\circ} \mathrm{E}$ & $28.97^{\circ} \mathrm{N}$ & & & 6 \\
\hline & Kecheng B & $118.87^{\circ} \mathrm{E}$ & $29.02^{\circ} \mathrm{N}$ & & & 1 \\
\hline & Kecheng C & $118.86^{\circ} \mathrm{E}$ & $29.05^{\circ} \mathrm{N}$ & & & 1 \\
\hline & Qujiang & $118.89^{\circ} \mathrm{E}$ & $29.00^{\circ} \mathrm{N}$ & & & 9 \\
\hline & Huangyan & $121.16^{\circ} \mathrm{E}$ & $28.63^{\circ} \mathrm{N}$ & & & 11 \\
\hline & Hunan & & & \multirow{4}{*}{ C. reticulata } & \multirow[t]{4}{*}{$\mathrm{HN}$} & 30 \\
\hline & Luxi A & $110.04^{\circ} \mathrm{E}$ & $28.24^{\circ} \mathrm{N}$ & & & 14 \\
\hline & Luxi B & $109.97^{\circ} \mathrm{E}$ & $28.26 \mathrm{~N}$ & & & 16 \\
\hline \multirow[t]{3}{*}{ Subtotal } & & & & & & 142 \\
\hline & Hunan & & & & & \\
\hline & Luxi A & $110.05^{\circ} \mathrm{E}$ & $28.24^{\circ} \mathrm{N}$ & C. reticulata & O1 & 25 \\
\hline \multirow[t]{3}{*}{ Orchard } & Luxi B & $109.97^{\circ} \mathrm{E}$ & $28.26^{\circ} \mathrm{N}$ & C. reticulata & $\mathrm{O} 2$ & 24 \\
\hline & Luxi C & $110.04^{\circ} \mathrm{E}$ & $28.24^{\circ} \mathrm{N}$ & C. sinensis & $\mathrm{O} 3$ & 28 \\
\hline & Luxi D & $110.10^{\circ} \mathrm{E}$ & $28.25^{\circ} \mathrm{N}$ & C. sinensis & $\mathrm{O} 4$ & 25 \\
\hline \multirow[t]{3}{*}{ Subtotal } & & & & & & 102 \\
\hline & Luxi E & $109.97^{\circ} \mathrm{E}$ & $28.23^{\circ} \mathrm{N}$ & C. reticulata & $\mathrm{T} 1$ & 16 \\
\hline & Luxi E & $109.97^{\circ} \mathrm{E}$ & $28.23^{\circ} \mathrm{N}$ & C. reticulata & $\mathrm{T} 2$ & 17 \\
\hline \multirow[t]{3}{*}{ Tree } & Luxi E & $109.97^{\circ} \mathrm{E}$ & $28.23^{\circ} \mathrm{N}$ & C. reticulata & T3 & 24 \\
\hline & Luxi E & $109.97^{\circ} \mathrm{E}$ & $28.23^{\circ} \mathrm{N}$ & C. reticulata & $\mathrm{T} 4$ & 18 \\
\hline & Luxi E & $109.97^{\circ} \mathrm{E}$ & $28.23^{\circ} \mathrm{N}$ & C. reticulata & $\mathrm{T} 5$ & 20 \\
\hline Subtotal & & & & & & 95 \\
\hline
\end{tabular}


The first level was the finest scale where we sampled extensively among five trees (the trees were at least $10 \mathrm{~m}$ from each other) in one orchard in Luxi county, Hunan Province. For each tree, five leaves and five fruits with melanose symptoms were sampled and 10 melanose spots per leaf/fruit were individually treated for isolation of D. citri. All host trees in this orchard were C. reticulata and a total of 95 isolates were obtained for study.

The second spatial level analyzed $D$. citri samples from four orchards within Luxi county in Hunan Province. Two of the four orchards had C. reticulata while the other two were planted with $C$. sinensis. Here, four leaves or fruits with melanose symptoms were randomly collected from each of 10 random trees (at least $10 \mathrm{~m}$ apart) in each orchard. A total of 102 isolates were obtained from these four orchards. At this level, we analyzed the potential effects of intermediate spatial separation and host tree species on the total genetic variations.

The third level is the largest spatial scale at the provincial level, where 142 isolates were collected from 18 orchards of $C$. reticulata located in five provinces. These included 24 isolates from four orchards in Fujian (FJ) Province, 30 isolates from three orchards in Guizhou (GZ) Province, 30 isolates from four orchards in Jiangxi (JX) Province, 28 isolates from five orchards in Zhejiang (ZJ) Province, and 30 isolates from two orchards in Hunan (HN) Province. Similar to the two smaller scales, each isolate was derived from an independent melanose spot on either leaves or fruits. Here, the isolates were derived from at least five trees in each orchard. For each tree, 1-4 leaves or fruits with melanose symptoms were randomly sampled for isolation of D. citri. However, to reduce the potential overrepresentation of isolates from certain trees, only one isolate from each tree was randomly chosen for genotyping and subsequent data analyses.

To minimize confounding factors, the three levels of analyses used separate samples. Strains of D. citri were isolated following the method described previously [2]. Cultures were stored at $4{ }^{\circ} \mathrm{C}$. For long-term storage, the isolates were kept in $30 \%$ glycerin in a $-80{ }^{\circ} \mathrm{C}$ freezer.

\subsection{DNA Extraction}

For each isolate, its genomic DNA was extracted from mycelia scraped off with a sterile blade from a colony growing on PDA at $25^{\circ} \mathrm{C}$ for about 7 days. The scraped mycelia were lyophilized, and then the DNA was extracted using a SIMGEN Fungi Kit (Simgen, Hangzhou, China) according to the manufacturer's protocol. The extracted genomic DNA samples were quantified using a Nanodrop spectrophotometer (Nanodrop Products, Wilmington, DE, USA) and stored in sterile water in a $-20{ }^{\circ} \mathrm{C}$ freezer.

\subsection{Identification of $D$. citri-like Isolates}

The obtained D. citri-like isolates were confirmed based on their colony morphology, microscopic conidia features, and molecular characteristics [2]. Specifically, we used $D$. citrispecific primer pair Dc-F/Dc-R (5'-CCCTCGAGGCATCATTAC-3' /5'-ATGTTGCAGATG GTCAAATGG-3') designed based on sequence variations in the Tub gene among 21 Diaporthe species from citrus [2]. Each PCR reaction was conducted in a final volume of $20 \mu \mathrm{L}$, containing $1 \mu \mathrm{L}$ of template genomic DNA ( $20 \mathrm{ng}), 0.8 \mu \mathrm{L}$ forward primer, $0.8 \mu \mathrm{L}$ reverse primer, $10 \mu \mathrm{L}$ of $2 \times$ Taq Plus Master Mix (Vazyme Biotechnology Co. Hangzhou), and $7.4 \mu \mathrm{L}$ sterile water. PCR cycling condition was performed as follows: $94^{\circ} \mathrm{C}$ for $3 \mathrm{~min}$, 31 cycles of $94{ }^{\circ} \mathrm{C}$ for $30 \mathrm{~s}, 60{ }^{\circ} \mathrm{C}$ for $30 \mathrm{~s}, 72{ }^{\circ} \mathrm{C}$ for $1 \mathrm{~min}$, with a final extension of $3 \mathrm{~min}$ at $72{ }^{\circ} \mathrm{C}$. The PCR products were analyzed by electrophoresis at $120 \mathrm{~V}$ for $30 \mathrm{~min}$ in a $1 \%$ $(w / v)$ agarose gel and visualized under UV light after ethidium bromide staining. Genomic DNAs from two strains (ZJUD2 and ZJUD14), which were identified as D. citri [2], were used as positive controls. The genomic DNAs of Diaporthe citriasiana strain ZJUD31 and D. citrichinensis strain ZJUD40 [2] were used as negative controls. These four reference isolates are stored at the Institute of Biotechnology at Zhejiang University (Hangzhou, Zhejiang Province, China). 


\subsection{SSR Marker Development and Screening}

The genome sequence of D. citri strain ZJUD2 [22] was screened using the online tool Batchprimer 3 (https:/ / wheat.pw.usda.gov/demos/BatchPrimer3/, accessed on 5 November 2020) [23] to identify potential SSR markers. SSRs containing 2 to 54 tandem repeats of di- to hexa-nucleotides as well as their flanking regions were retrieved. Primers were designed using Batchprimer 3 following the default setting to obtain amplification products in the range of $100 \mathrm{bp}$ to $250 \mathrm{bp}$ to allow optimum genotyping and scoring [24]. The selected primers were screened for levels of polymorphism and amplification success using a subset of 12 isolates of D. citri (ZJUD2, ZJUD6, ZJUD14, ZJUD26, ZJUD13, ZJUD24, ZJUD22, ZJUD28, ZJUD19, ZJUD21, ZJUD15, and ZJUD8) [2], which were kept at the Institute of Biotechnology at Zhejiang University. The PCR cycling conditions used the following touch-down protocol: $94{ }^{\circ} \mathrm{C}$ for $5 \mathrm{~min}, 10$ cycles of $94{ }^{\circ} \mathrm{C}$ for $30 \mathrm{~s}, 60^{\circ} \mathrm{C}$ for $30 \mathrm{~s}$, with a decrease in annealing temperature of $1{ }^{\circ} \mathrm{C}$ in each cycle, and $72{ }^{\circ} \mathrm{C}$ for $30 \mathrm{~s}$, followed by 25 cycles of $94{ }^{\circ} \mathrm{C}$ for $30 \mathrm{~s}, 52^{\circ} \mathrm{C}$ for $30 \mathrm{~s}$, and $72{ }^{\circ} \mathrm{C}$ for $30 \mathrm{~s}$, with a final extension of $10 \mathrm{~min}$ at $72{ }^{\circ} \mathrm{C}$. The PCR products were separated on polyacrylamide gels and stained with ethidium bromide before visualization under UV light. Loci were considered polymorphic if two or more alleles were observed among the 14 isolates evaluated.

Based on amplification success and the level of polymorphisms, we selected 14 markers to genotype the subset of 14 isolates from our recent collection. The optimum annealing temperature of the selected 14 pairs of primers was derived by gradient PCR using the genome DNA of ZJUD2. The PCR reaction system was the same as described above. The PCR cycling conditions were: $94{ }^{\circ} \mathrm{C}$ for $5 \mathrm{~min}, 31$ cycles of $94{ }^{\circ} \mathrm{C}$ for $30 \mathrm{~s}, 50 \sim 62{ }^{\circ} \mathrm{C}$ for $30 \mathrm{~s}, 72{ }^{\circ} \mathrm{C}$ for $30 \mathrm{~s}$, with a final extension of $5 \mathrm{~min}$ at $72{ }^{\circ} \mathrm{C}$. The PCR products were separated and visualized as described above for confirmation of amplification success and polymorphisms among the 14 representative strains. All 14 primer pairs successfully amplified a single product from each of the 14 representative strains. These 14 primer pairs were then used to genotype all 339 isolates following protocols described below.

\subsection{SSR Loci Genotyping}

For each of the 14 SSR markers, the forward primer was labeled with either FAM, HEX, or TAMRA fluorophore. The PCR reaction system was the same as described above. PCR cycling was performed as follows: $94{ }^{\circ} \mathrm{C}$ for $5 \mathrm{~min}, 35$ cycles of $94{ }^{\circ} \mathrm{C}$ for $30 \mathrm{~s}$, 53,55 , or $56{ }^{\circ} \mathrm{C}$ (depending on the primer pair) for $30 \mathrm{~s}, 72{ }^{\circ} \mathrm{C}$ for $30 \mathrm{~s}$, with a final extension of $10 \mathrm{~min}$ at $72{ }^{\circ} \mathrm{C}$. The amplicons were separated using capillary electrophoresis. Capillary electrophoresis was performed in multiplex reactions of three amplicons with three different fluorescent dyes per reaction. The PCR products were analyzed using an ABI 3730xl Genetic Analyzer (Applied Biosystems, Foster City, CA, USA) with a GS500LIZ Size Standard (Applied Biosystems). The output files were analyzed using GeneMapper v4.1 software (Applied Biosystems) to identify the lengths of amplified fragments at each locus.

\subsection{Diversity Characteristics of the 14 SSR Markers}

For most diversity estimates, two sets of samples were analyzed: non-clone-corrected (i.e., the raw sample) and clone-corrected. For clone-corrected datasets, only a single isolate of each multilocus genotype (MLG) was retained from each sub-population. Isolates with the same alleles at all loci were considered as belonging to the same clone. Clone-corrected datasets were used to minimize potentially distorted estimates of allelic diversity due to differences in sampling efforts and in D. citri isolation successes [25].

To determine gene diversities of the subpopulations and populations at different spatial scales, the following diversity estimates were calculated using the program GenAlEx v. 6.5.2 [26]: number of alleles (Na), number of private alleles, effective number of alleles, Shannon's polymorphism information index [27], Nei's gene diversity [28], and unbiased gene diversity [29]. 
To determine the genotypic diversities in subpopulations and populations at each of the three spatial scales, the number of MLGs was determined in R v. 3.6.3 (R Core Team 2013) [30] using the analysis package poppr [31]. Genetic and genotypic diversities were not calculated for samples from individual trees and orchards due to their small numbers of isolates. To assess the power of our SSR markers for discriminating between strains and multilocus genotypes in the dataset, a rarefaction curve was generated using poppr [31].

\subsection{Genetic Structure Analysis of D. citri Populations}

Population genetic structure was analyzed using several approaches. In the first, we analyzed the sources of genetic variation at different spatial scales using GenAlEx version 6.501 [26]. The relationships among geographic subpopulations were investigated based on clone-corrected data using hierarchical analysis of molecular variance (AMOVA) at different scales, using 999 permutations. The PhiPT values, representing a 0 to 1 scaled estimator of population differentiation [32], were calculated with clone-corrected data for all pairwise comparisons for subpopulations from different provinces using 999 permutations. Principal Component Analysis (PCA) was also performed to highlight the genetic similarities and differences among the provincial subpopulations. In the second analysis, we assessed the relationships among the MLGs in the subpopulations from Fujian, Guizhou, Jiangxi, Zhejiang, and Hunan provinces, using a minimum spanning network approach to analyze the non-clone-corrected data based on Bruvo's distance [33], using the R package poppr.

In the third approach, we used the program STRUCTURE v. 2.3.4 [34] to infer the number of genetic clusters in the total sample, as well as to estimate the extent to which genetic admixture might have occurred among the subpopulations from the five provinces. The STRUCTURE analyses used the admixture model, with 10 replicated runs of $K=1$ to 10 after an initial burn-in of 100,000 generations followed by a run length of $1,000,000$ generations. The optimal number of genetic clusters $(K)$ was identified by following the method described in [35], using StructureHarvester (http:/ / taylor0.biology.ucla. edu/structureHarvester, accessed on 1 June 2021).

At the two smaller spatial scales, we also used GenAlEx to identify the potential influences of two host species (C. reticulata vs. C. sinensis among geographically closely located orchards within Luxi county in Hunan) and two host organs (leaves vs. fruits of the same five trees within one orchard) on the observed genetic variations, respectively.

\subsection{Mating Type Identification}

The sequences of MAT1-1-1 and MAT1-2-1 in D. citri were identified by BLASTP searches against the $D$. citri genomes of strains ZJUD14 (GCA_014872985.1) and ZJUD2 (GCA_014872965.1), which contained MAT1-1-1 and MAT1-2-1, respectively [22]. In these searches, we used protein sequences of Diaporthe W-type (MAT1-1-1: AB199324, MAT1-2-1: AB199325) and Diaporthe G-type (MAT1-1-1: AB199324, MAT1-2-1: AB199325) [21] as query sequences and designed the $D$. citri-specific MAT1-1-1 primer pair DcM1F/DcM1R (5'-ATGTGGCACAAAGAAATCC-3' $/ 5^{\prime}$-TCACTGGAGGTCCCAATTG-3') and MAT1-2-1 primer pair DcM2F/DcM2R (5'-ATGTGGCACAAAGAAATCC-3' / 5'-TCACTGGAGGTCC CAATTG-3 $\left.3^{\prime}\right)$, respectively, using the Primer Premier 5 software $[24,36]$. These primers were used to amplify the mating type loci of all 339 isolates of D. citri in this study. Each PCR reaction had a final volume of $25 \mu \mathrm{L}$, containing $1 \mu \mathrm{L}$ of template genomic DNA ( $20 \mathrm{ng})$, $1 \mu \mathrm{L}$ forward primer, $1 \mu \mathrm{L}$ reverse primer, $12.5 \mu \mathrm{L}$ of $\times$ Taq Plus Master Mix (Vazyme Biotechnology Co. Hangzhou), and $9.5 \mu \mathrm{L}$ sterile water. PCR cycling was performed as follows: $94{ }^{\circ} \mathrm{C}$ for $5 \mathrm{~min}, 35$ cycles of $94^{\circ} \mathrm{C}$ for $30 \mathrm{~s}, 55^{\circ} \mathrm{C}$ (MAT1-2-1) or $56^{\circ} \mathrm{C}$ (MAT1-1-1) for $30 \mathrm{~s}, 72{ }^{\circ} \mathrm{C}$ for $1 \mathrm{~min}$, with a final extension of $7 \mathrm{~min}$ at $72{ }^{\circ} \mathrm{C}$. After the amplification products of MAT1-1-1 and MAT1-2-1 were mixed, $4 \mu \mathrm{L}$ of the mixture was separated on $1 \%$ agarose gel for electrophoresis $(130 \mathrm{~V}, 30 \mathrm{~min})$ and visualized under $\mathrm{UV}$ light after ethidium bromide staining. 


\subsection{Mating Type Ratios}

The ratios of the MAT1-1-1 and MAT1-2-1 mating types among the isolates at each subpopulation and in the total population were calculated based on both the non-clonecorrected and clone-corrected datasets. A $\chi^{2}$ test with a critical value of $p<0.05$ was performed to determine whether the mating type frequencies deviated significantly from a 1:1 ratio [37]. The null hypothesis was that the ratio of the two mating types was 1:1 (in equilibrium). Due to issues with using a $\chi^{2}$ test when analyzing small sample sizes, an exact binomial goodness-of-fit test (two-tailed) was also performed to assess whether the observed mating type ratios for analyzed populations deviated from 1:1. The $\chi^{2}$ test and the exact binomial test (two-tailed) were performed using IBM SPSS Statistics 20 (International Business Machines Corporation, Arkmonk, NY, USA). Occurrence of the two mating types in equilibrium would be an indication of sexual reproduction and recombination.

\subsection{Analysis of Linkage Disequilibrium and Recombination}

Linkage disequilibrium was analyzed by calculating the index of association $\left(\mathrm{I}_{\mathrm{A}}\right)[38]$ and the standardized index of association $\left(\overline{\mathrm{r}}_{\mathrm{d}}\right)$ [39] after 999 permutations in package poppr [31]. The null hypothesis in this test was that frequent recombination occurred and would be seen as random associations among alleles among the 14 different loci. Significant deviations from random associations would result in rejection of the null hypothesis and support the alternative hypothesis of linkage, indicating infrequent or no recombination in nature. In addition, we also tested whether the null hypothesis of no recombination would be supported. Here, the proportion of phylogenetically compatible pairs of loci (Prp) was calculated using Multilocus 1.3b with 1000 permutations. Two loci are phylogenetically compatible ( $\operatorname{Prp}=1$ ) if they arise from the same phylogenetic position in the absence of homoplasy or recombination. Under the assumption that parallels, reversals, or convergences are rare, phylogenetic incompatibility $(\operatorname{Prp}<1)$ provides the evidence of sexual recombination and exchange of genetic material between genomes [40,41]. The hypothesis of random mating would be rejected if fewer incompatible pairs of loci were observed than expected in a randomized recombining population $(p<0.05)$ [39].

\section{Results}

\subsection{SSR Marker Development and Screening}

The fourteen primer pairs we screened showed polymorphisms in the subset of 14 isolates (data not shown). The BLAST analyses of the 14 SSRs using the assembled $D$. citri genome showed that these 14 SSR loci were all located on different contigs and not closely linked. The details about these 14 loci are presented in Table 2.

\subsection{Diversity Characteristics of the 14 SSR Markers in the D. citri Population}

At the largest spatial scale that includes the five provincial populations, all 14 loci were polymorphic, and the number of alleles per locus among the 142 isolates ranged from 4 to 20, Nei's gene diversity ranged from 0.40 to 0.89 , Simpson index ranged from 0.39 to 0.89 , and Evenness ranged from 0.42 to 0.86 . At the next spatial scale among the four orchards used for analyzing potential local population structuring and host tree effects on pathogen gene diversity, 13 of the 14 loci were polymorphic, while the DC1 locus was monomorphic among the 102 isolates. The number of amplified alleles, Simpson index, Nei's gene diversity, and Evenness per locus among the 102 isolates ranged from 2 to 15 , 0.04 to $0.78,0.04$ to 0.79 , and 0.35 to 0.88 in the orchard population, respectively (Table 3 ). Similarly, 13 of the 14 loci were polymorphic among the 95 isolates from the five trees in the same orchard, with locus DC1 being monomorphic. The number of amplified alleles, Simpson index, Nei's gene diversity, and Evenness per locus ranged from 2 to 13, 0.11 to $0.80,0.11$ to 0.81 , and 0.39 to 0.89 in the tree population, respectively (Table 3 ). The genotype rarefaction curve showed increases in the number of genotypes as the number of the loci increased at all three examined spatial scales and reached a plateau at 13 loci at the provincial level, and at 12 loci at the orchard and tree levels (Figure 1). Together, these 
results indicate that the 14 SSR markers were sufficient to discriminate among strains at the three spatial scales.

Table 2. Information of primer pairs and product size range for the 14 SSR loci analyzed in this study.

\begin{tabular}{|c|c|c|c|c|c|}
\hline Locus & $\begin{array}{l}\text { Repeat } \\
\text { Motif }\end{array}$ & Primer Sequence $\left(5^{\prime}\right.$ to $\left.3^{\prime}\right)$ & $\begin{array}{l}\text { Product } \\
\text { Size }\end{array}$ & OAT $^{1}$ & $\begin{array}{l}\text { Labeling } \\
\text { Dye }\end{array}$ \\
\hline DC8 & $(\mathrm{TG})_{16}$ & $\begin{array}{l}\text { F: GTGCTTCTCTTGTTGTTTGTT } \\
\text { R: AACTTTCCTTTCCCTTCTTCT }\end{array}$ & $128-250$ & $55^{\circ} \mathrm{C}$ & FAM \\
\hline DC13 & $(\mathrm{GGT})_{9}$ & $\begin{array}{l}\text { F: GGTGGAGATGAACCCTTC } \\
\text { R: CGCCTGGTACGTTACATT }\end{array}$ & $124-151$ & $53^{\circ} \mathrm{C}$ & FAM \\
\hline DC2 & $(\mathrm{AG})_{9}$ & $\begin{array}{l}\text { F: TGAATTGGGAGAAAGAGAGAC } \\
\text { R: TGGTAACAGACCAAGATGATT }\end{array}$ & $121-141$ & $56^{\circ} \mathrm{C}$ & FAM \\
\hline DC31 & $(\mathrm{CA})_{20}$ & $\begin{array}{l}\text { F: GACTATCGCACTTACAACTGG } \\
\text { R: ACTTCCAAAGGGTATTTGTGT }\end{array}$ & 157-197 & $55^{\circ} \mathrm{C}$ & FAM \\
\hline DC41 & $(\mathrm{CTGC})_{11}$ & $\begin{array}{l}\text { F: AAACTGCTGCAGAACATCTC } \\
\text { R: GATCTGGGTCAGGATCGTA }\end{array}$ & 144-196 & $56^{\circ} \mathrm{C}$ & TAMRA \\
\hline DC10 & $(\mathrm{TG})_{8}$ & $\begin{array}{l}\text { F: GATGGAGAACACAGAGATGAA } \\
\text { R: ATATCAACATTCTGACCACCA }\end{array}$ & $214-264$ & $55^{\circ} \mathrm{C}$ & TAMRA \\
\hline DC39 & $(\mathrm{CA})_{29}$ & $\begin{array}{l}\text { F: GTCTGTCTCCTTGTGTCTCTC } \\
\text { R: AAACGTTCCCCTTCTCTAAC }\end{array}$ & $100-156$ & $55^{\circ} \mathrm{C}$ & TAMRA \\
\hline DC54 & $(\mathrm{AC})_{33}$ & $\begin{array}{l}\text { F: AGTCCGTCCAATGTCTGTC } \\
\text { R: TGCATATGTTGTGCTTTGTT }\end{array}$ & 99-193 & $55^{\circ} \mathrm{C}$ & TAMRA \\
\hline DC43 & $(\mathrm{CT})_{33}$ & $\begin{array}{l}\text { F: CTCTCTCACACACACACACAC } \\
\text { R: TAGCTGTAGATGAGTCCCAGA }\end{array}$ & $130-238$ & $53^{\circ} \mathrm{C}$ & TAMRA \\
\hline DC14 & $(\mathrm{CA})_{8}$ & $\begin{array}{c}\text { F: CTCCCTCTTCCCAGACAC } \\
\text { R: AGAGGAGGTTGTATTTTGTGTT }\end{array}$ & $156-214$ & $55^{\circ} \mathrm{C}$ & HEX \\
\hline DC27 & $(\mathrm{CACT})_{12}$ & $\begin{array}{l}\text { F: AAATCACCCCACACTCAAC } \\
\text { R: AGACATGGAGCAACACAAGT }\end{array}$ & $110-138$ & $55^{\circ} \mathrm{C}$ & HEX \\
\hline DC4 & $(\mathrm{CAG})_{10}$ & $\begin{array}{c}\text { F: ATCACACCTTTCATCTCATCA } \\
\text { R: CGAGAGTTTCTCTCCTTGG }\end{array}$ & $136-157$ & $55^{\circ} \mathrm{C}$ & HEX \\
\hline DC1 & $(\mathrm{AG})_{11}$ & $\begin{array}{l}\text { F: CTCCAGCATGACATAGTTAGG } \\
\text { R: CTGGTCTGATCTGTAAGTGGA }\end{array}$ & $156-170$ & $53^{\circ} \mathrm{C}$ & HEX \\
\hline DC55 & $(\mathrm{AC})_{9}$ & $\begin{array}{l}\text { F: ATTTCCTCTCAAGCACAATG } \\
\text { R: ATGGTCCAGTCACAAACATAG }\end{array}$ & $154-282$ & $55^{\circ} \mathrm{C}$ & HEX \\
\hline
\end{tabular}

${ }^{1}$ OAT, optimal annealing temperature.

Table 3. Polymorphism of 14 SSR loci at the provincial, orchard, and tree populations of D. citri ${ }^{1}$.

\begin{tabular}{cccccccccccccc}
\hline & \multicolumn{4}{c}{ Province } & \multicolumn{4}{c}{ Orchard } & \multicolumn{4}{c}{ Tree } \\
\cline { 2 - 13 } & $\mathbf{N a}$ & $\boldsymbol{\lambda}$ & Hexp & $\mathbf{E}$ & $\mathbf{N a}$ & $\boldsymbol{\lambda}$ & Hexp & $\mathbf{E}$ & $\mathbf{N a}$ & $\boldsymbol{\lambda}$ & Hexp & $\mathbf{E}$ \\
\hline DC1 & 6 & 0.67 & 0.68 & 0.69 & 6 & 0.74 & 0.75 & 0.85 & 5 & 0.64 & 0.65 & 0.84 \\
DC2 & 4 & 0.45 & 0.45 & 0.65 & 4 & 0.46 & 0.46 & 0.68 & 2 & 0.19 & 0.19 & 0.58 \\
DC4 & 4 & 0.57 & 0.57 & 0.74 & 1 & 0.00 & 0.00 & NA & 1 & 0.00 & 0.00 & NA \\
DC8 & 20 & 0.84 & 0.84 & 0.62 & 15 & 0.78 & 0.79 & 0.64 & 13 & 0.79 & 0.80 & 0.65 \\
DC10 & 13 & 0.84 & 0.85 & 0.78 & 9 & 0.64 & 0.64 & 0.57 & 8 & 0.80 & 0.81 & 0.83 \\
DC13 & 5 & 0.39 & 0.40 & 0.55 & 3 & 0.10 & 0.10 & 0.41 & 2 & 0.11 & 0.11 & 0.49 \\
DC14 & 13 & 0.89 & 0.89 & 0.86 & 8 & 0.70 & 0.71 & 0.66 & 8 & 0.61 & 0.61 & 0.54 \\
DC27 & 5 & 0.65 & 0.66 & 0.77 & 3 & 0.06 & 0.06 & 0.37 & 2 & 0.11 & 0.11 & 0.49 \\
DC31 & 10 & 0.53 & 0.54 & 0.45 & 2 & 0.04 & 0.04 & 0.40 & 4 & 0.11 & 0.11 & 0.39 \\
DC39 & 12 & 0.79 & 0.79 & 0.71 & 5 & 0.74 & 0.74 & 0.88 & 5 & 0.72 & 0.73 & 0.89 \\
DC41 & 7 & 0.68 & 0.68 & 0.73 & 4 & 0.32 & 0.32 & 0.58 & 5 & 0.39 & 0.39 & 0.51 \\
DC43 & 14 & 0.75 & 0.75 & 0.61 & 5 & 0.62 & 0.62 & 0.79 & 4 & 0.57 & 0.58 & 0.84 \\
DC54 & 11 & 0.50 & 0.51 & 0.42 & 5 & 0.10 & 0.10 & 0.35 & 3 & 0.17 & 0.17 & 0.50 \\
DC55 & 5 & 0.58 & 0.58 & 0.71 & 2 & 0.27 & 0.27 & 0.67 & 2 & 0.22 & 0.22 & 0.61 \\
Mean & 9 & 0.65 & 0.66 & 0.66 & 5 & 0.40 & 0.40 & 0.60 & 5 & 0.39 & 0.39 & 0.63 \\
\hline
\end{tabular}

${ }^{1}$ Calculated based on clone-corrected data. Na, Number of alleles; $\lambda$, Simpson index; Hexp, Nei's gene diversity;

E, Evenness, the distribution of genotype abundance. 

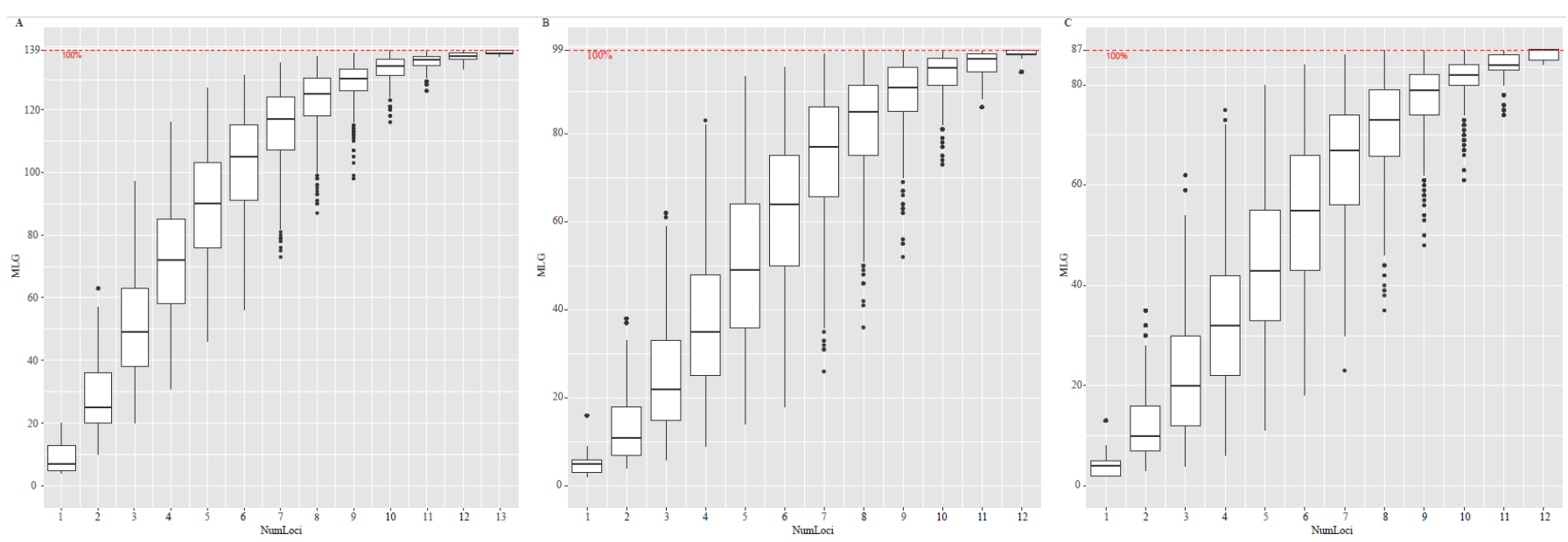

Figure 1. Genotype rarefaction curve for 14 SSR loci used to identify multilocus genotypes of Diaporthe citri populations from provincial (A), orchard (B), and tree (C) scales.

The above results on gene diversities described the variations among the 14 loci at different spatial scales. When all loci are considered, individual populations at all three spatial scales also showed high diversities. For example, the numbers of different and effective alleles per locus ranged from 2.957 (tree level) to 4.104 (provincial level) and 1.920 (orchard level) to 2.466 (provincial level); the Shannon's information indices were $0.908,0.684$, and 0.681 ; and the unbiased Nei's diversities were $0.472,0.348$, and 0.363 for populations at provincial, orchard, and tree scales, respectively. The values of unbiased allelic diversities were overall similar to Nei's diversity (Table 4).

Table 4. Genetic diversity of Diaporthe citri subpopulations at three different spatial scales in China ${ }^{1}$.

\begin{tabular}{ccccccccc}
\hline Scale & Subpopulations & $\mathbf{N}$ & MLGs & eMLGs & Ne & I & h & uH \\
\hline \multirow{6}{*}{ Provincial } & FJ & 24 & 24 & 24.00 & 3.254 & 1.252 & 0.638 & 0.665 \\
& GZ & 30 & 29 & 23.37 & 2.289 & 0.809 & 0.420 & 0.435 \\
& JX & 30 & 30 & 24.00 & 1.840 & 0.604 & 0.350 & 0.362 \\
& ZJ & 28 & 27 & 23.27 & 2.780 & 1.132 & 0.569 & 0.591 \\
& HN & 30 & 29 & 23.37 & 2.165 & 0.745 & 0.382 & 0.395 \\
& Total & 142 & 139 & 23.92 & 2.466 & 0.908 & 0.472 & 0.490 \\
\hline \multirow{6}{*}{ Orchard } & O1 & 25 & 23 & 22.16 & 1.988 & 0.729 & 0.378 & 0.395 \\
& O2 & 24 & 23 & 23.00 & 1.923 & 0.677 & 0.348 & 0.363 \\
& O3 & 28 & 28 & 24.00 & 2.061 & 0.736 & 0.374 & 0.388 \\
& O4 & 25 & 25 & 24.00 & 1.768 & 0.610 & 0.314 & 0.327 \\
& Total & 102 & 99 & 23.84 & 1.920 & 0.684 & 0.348 & 0.360 \\
\hline \multirow{5}{*}{ Tree } & T1 & 16 & 10 & 10.00 & 1.907 & 0.585 & 0.314 & 0.349 \\
& T2 & 17 & 17 & 16.00 & 2.099 & 0.704 & 0.374 & 0.397 \\
& T3 & 24 & 24 & 16.00 & 2.120 & 0.711 & 0.375 & 0.391 \\
& T4 & 18 & 16 & 14.43 & 2.273 & 0.771 & 0.409 & 0.436 \\
& T5 & 20 & 20 & 16.00 & 1.935 & 0.637 & 0.346 & 0.364 \\
& Total & 95 & 87 & 15.58 & 2.067 & 0.681 & 0.363 & 0.388 \\
\hline
\end{tabular}

${ }^{1}$ Data on $\mathrm{Ne}, \mathrm{I}, \mathrm{h}$, and uh in this table were based on clone-corrected samples. MLGs, multilocus genotypes; eMLGs, expected multilocus genotypes; N, Number of isolates; Ne, Number of effective alleles; I, Shannon's information index; $\mathrm{H}$, Nei's gene diversity (Nei, 1973) across all loci; $\mathrm{uH}$, Nei's unbiased genotypic diversity. MLG and eMLG were calculated in $\mathrm{R}$ v. 3.6.3 using the analysis package poppr, and $\mathrm{Ne}, \mathrm{I}, \mathrm{H}$, and $\mathrm{uH}$ were calculated in GenAlEx version 6.502.

Among the five provincial subpopulations, that from Fujian Province showed the highest gene diversity, with Nei's gene diversity and Shannon's information index being 0.638 and 1.252, respectively, followed by the Zhejiang subpopulation with Nei's gene diversity and Shannon's information index at 0.569 and 1.132, respectively. The levels of gene diversity of the Hunan, Jiangxi, and Guizhou subpopulations were similar, with Nei's 
gene diversity and Shannon's information index ranging from 0.403 to 0.424 and 0.839 to 0.874 , respectively (Table 4 ).

Similar to gene diversity analyses, results from the genotype diversity analysis also revealed high genotypic diversities within all examined populations, with 139 (98\%), 99 (97\%), and 87 (92\%) MLGs identified among 142, 102, and 95 fungal isolates analyzed from the provincial, orchard, and tree levels, respectively (Table 4). At the provincial level, three of the 139 MLGs were shared, with each shared MLG found between two isolates from different trees in the same orchard. One shared MLG each was found in Guizhou, Hunan, and Zhejiang provinces (Table 4). Similarly, at the orchard level, three of the 99 MLGs were shared, with each shared MLG found between two isolates from different trees in the same orchard. Two of the shared MLGs were in orchard 1 and the third shared MLG was found in orchard 2 (O2 in Table 4). Interestingly, among the five trees within the same orchard, there was no shared MLG in our sample-all the shared MLGs were found among isolates either from different leaves/fruits on the same tree or from different melanose spots on the same leaf and fruit (Figure 2).

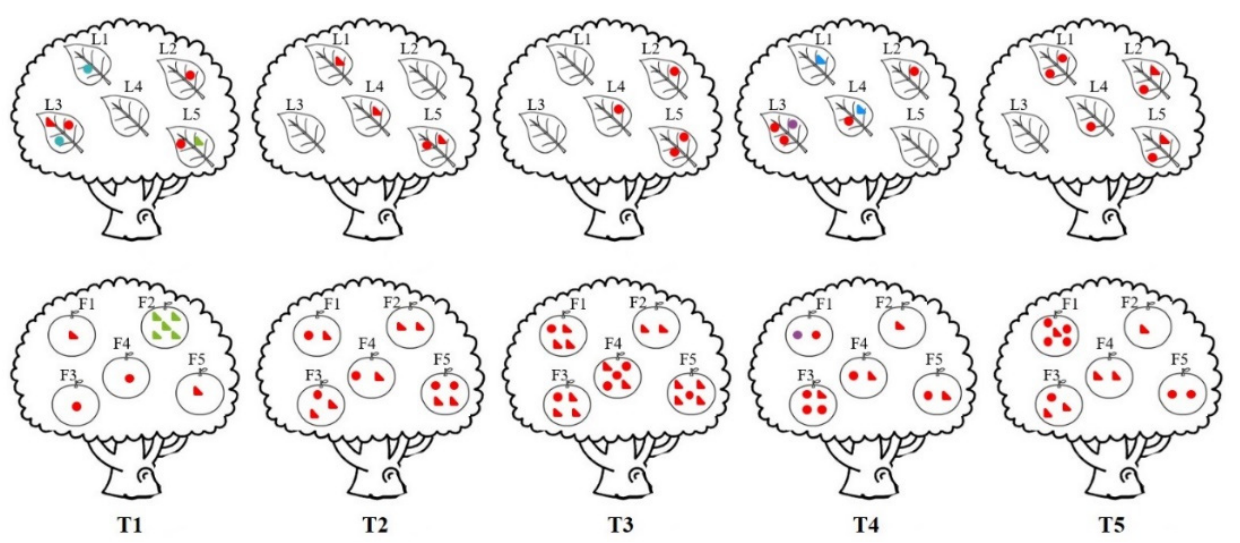

Figure 2. Distribution of two mating types within and among trees. $(\bullet)$ represents MAT1-1-1 isolates, (৯) represents MAT1-2-1 isolates. The isolates in red color have unique MLGs. Isolates in other colors hhave shared MLGs with isolates of the same colors. T1 T5 indicate tree1 tree5, L1 L5 indicate leaf 1 leaf 5, F1 F5 indicate fruit 1 fruit 5.

\subsection{Genetic Structure among Populations of D. citri}

AMOVA analysis showed that $31 \%$ of the genetic variation was distributed among the subpopulations from the five provinces, and $69 \%$ was distributed within the subpopulations. At the orchard level, $10 \%$ of the total genetic variations were distributed among the four orchards, while $90 \%$ were found within the orchards, with less than $2 \%$ coming from between the two citrus species $(p>0.05)$, consistent with limited host tree specialization in D. citri genotypes. At the tree level within the orchard in Luxi, $1 \%$ of the total genetic variations were found among the subpopulations from the five trees, while $99 \%$ were found within the individual tree subpopulations (Figure 3). Furthermore, there was no evidence of genetic differentiation between $D$. citri populations from the two different organ types (leaf vs. fruit) (Figure 4).

Pairwise PhiPT values showed significant genetic differentiation between all provincial subpopulations $(p=0.001)$, with the PhiPT values ranging from 0.104 (HN vs. GZ) to 0.421 (FJ vs. JX) (Table 5). PCA analysis revealed that the subpopulations from five provinces were divided into two genetic groups. One group included subpopulations from Hunan, Guizhou, and Jiangxi, while the other group included subpopulations from Fujian and Zhejiang (Figure 5). The minimum spanning network revealed that the MLGs from Fujian and Zhejiang are distinct from the Hunan, Guizhou, and Jiangxi subpopulations (Figure 6). 


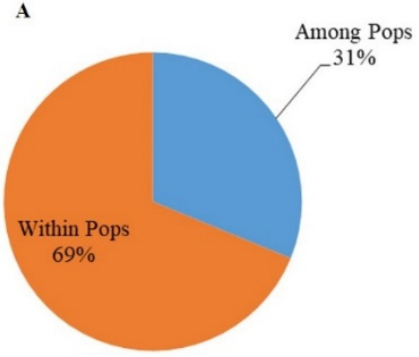

B

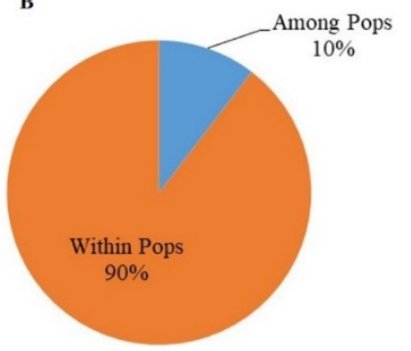

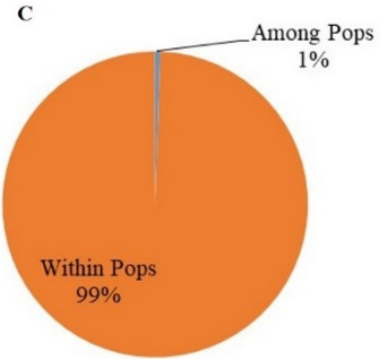

Figure 3. Analysis of molecular variance for Diaporthe citri subpopulations at the provincial (A), orchard (B), and tree (C) levels.
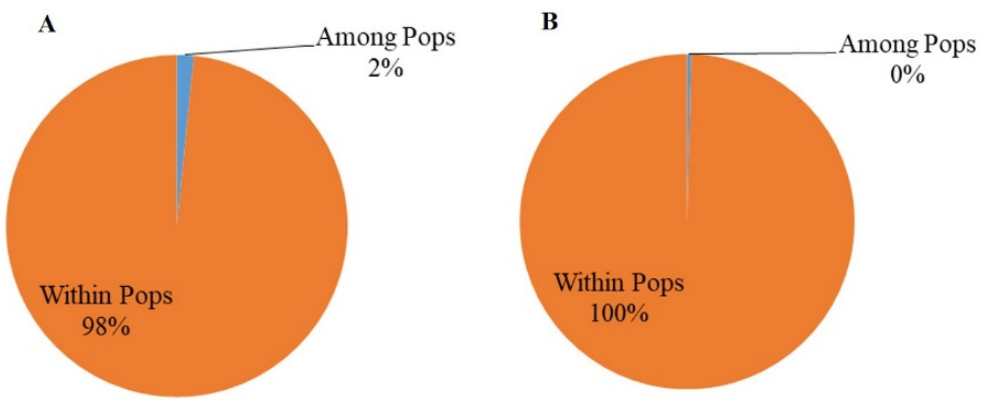

Figure 4. Analysis of molecular variance for Diaporthe citri populations between host tree speciesbased populations at orchard scale (A) and between organ type-based populations at the tree scale (B).

Table 5. PhiPT values among five provincial subpopulations of Diaporthe citri in southern China ${ }^{1}$.

\begin{tabular}{cccccc}
\hline Subpopulations & FJ & GZ & JX & ZJ & HN \\
\hline FJ & 0.000 & 0.001 & 0.001 & 0.001 & 0.001 \\
GZ & 0.387 & 0.000 & 0.001 & 0.001 & 0.001 \\
JX & 0.421 & 0.323 & 0.000 & 0.001 & 0.001 \\
ZJ & 0.144 & 0.299 & 0.298 & 0.000 & 0.001 \\
HN & 0.419 & 0.104 & 0.292 & 0.325 & 0.000 \\
\hline
\end{tabular}

${ }^{1}$ Data were clone-corrected. The values above the diagonal line indicate the $p$ values. The values below the diagonal line are the PhiPT values.

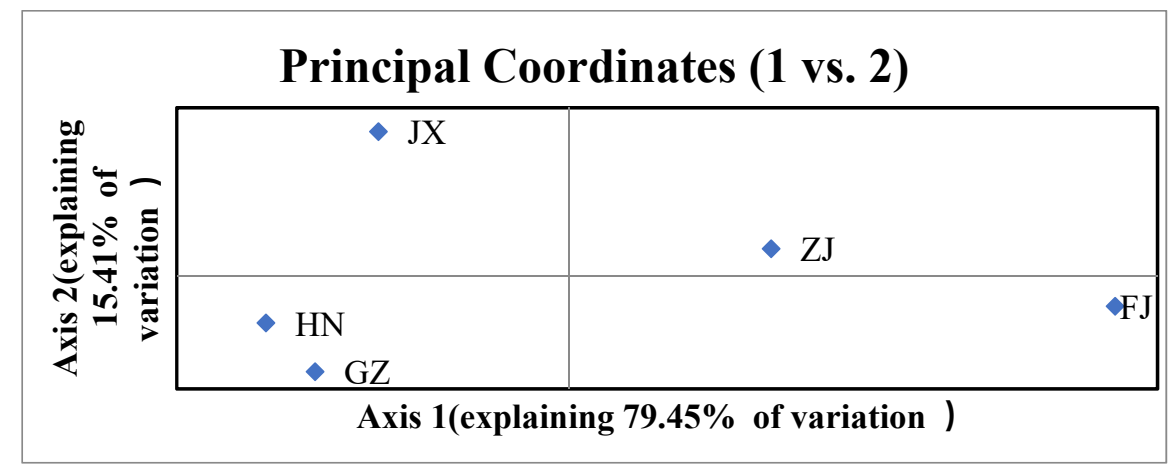

Figure 5. Principal component analysis for subpopulations from five provinces. FJ, GZ, JX, ZJ, and HN represent Fujian, Guizhou, Jiangxi, Zhejiang, and Hunan provinces, respectively. The data are clone-corrected. 


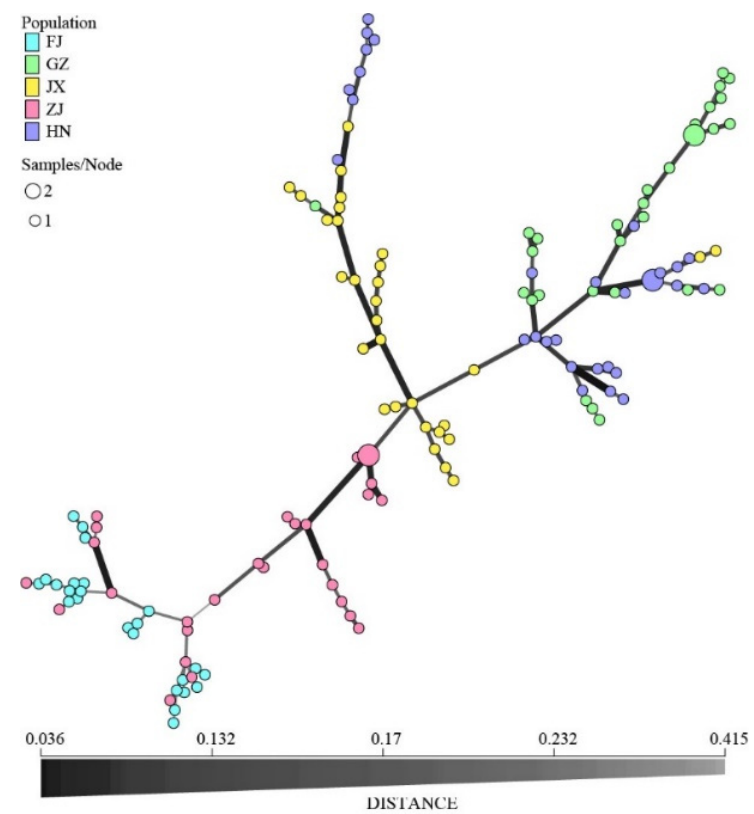

Figure 6. Minimum spanning network for subpopulations from five provinces. FJ, GZ, JX, ZJ, and HN represent Fujian, Guizhou, Jiangxi, Zhejiang, and Hunan provinces, respectively. The different colored circles represent the individuals of different provincial subpopulations, and the circle size represents the number of isolates with the same MLG. The data are clone-corrected.

The STRUCTURE analysis also identified two genetic clusters $(\mathrm{K}=2)$. However, isolates in the two genetic clusters showed different frequency distributions among the five provincial subpopulations. Isolates of one genetic cluster were distributed mostly in the Fujian subpopulations, and the other genetic cluster was mainly distributed in subpopulations from Hunan, Jiangxi, and Guizhou provinces. The Zhejiang subpopulation had similar representations of both genetic clusters (Figure 7). The results of the STRUCTURE analysis are consistent with the results of the pairwise PhiPT comparisons, the PCA, and minimum spanning network (MSN), which indicated low-level gene flow among five provinces' subpopulations. Interestingly, isolates with genetic elements of both clusters were found in all five provinces, consistent with the presence of hybridization among these geographic populations.

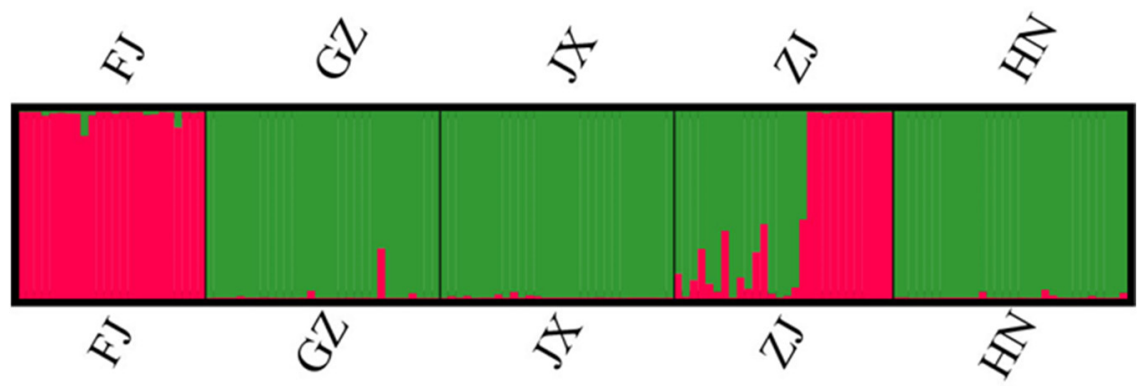

Figure 7. Structure results of the five provincial subpopulations. Different colors represent different genetic clusters $(K=2)$ with each vertical line representing an isolate. Data were clone-corrected.

Mantel analysis showed significant correlation between genetic and geographic distances $(r=0.7228, p=0.001)$, consistent with geographic separation playing a significant role in the genetic differentiation among these five provincial populations. 


\subsection{Mating Type Identification and Ratios}

A positive PCR amplification was obtained for all isolates with either primer pair DcM1F/DcM1R, which is specific to isolates of mating type MAT1-1, or primer pair DcM2F/DcM2R, which is specific to isolates of mating type MAT1-2. In populations at all three spatial scales of analyses, the mating type frequencies did not deviate significantly from a 1:1 ratio based on the $\chi^{2}$ test (non-clone-corrected data, $0.166 \leq p \leq 0.918$; clonecorrected data, $0.132 \leq p \leq 0.932$ ) and the exact binomial analysis (non-clone-corrected data, $0.198 \leq p \leq 1$; clone-corrected data, $0.159 \leq p \leq 1$ ) (Table 6). Indeed, within each subpopulation from a province, orchard, and tree, the mating types were also in similar frequencies (Table 6). Furthermore, the two mating types were found to co-exist on 13 of the $19(68 \%)$ fruits and 6 of the $9(67 \%)$ leaves from which at least two isolates were obtained for analyses (Figure 2).

Table 6. Ratio of the two mating types within subpopulations at three different spatial scales.

\begin{tabular}{|c|c|c|c|c|c|c|c|c|c|}
\hline \multirow{2}{*}{ Scale } & \multirow{2}{*}{ Subpopulation } & \multicolumn{4}{|c|}{ Raw Data } & \multicolumn{4}{|c|}{ Clone-Corrected Data } \\
\hline & & MAT1-1 & MAT1-2 & $\chi^{2}(p)^{a}$ & $p^{\mathrm{b}}$ & MAT1-1 & MAT1-2 & $\chi^{2}(p)$ & $p$ \\
\hline \multirow{6}{*}{ Province } & $\mathrm{FJ}$ & 11 & 13 & $0.167(0.683)$ & 0.839 & 11 & 13 & $0.167(0.683)$ & 0.839 \\
\hline & GZ & 15 & 15 & $0.000(1)$ & 1 & 15 & 14 & $0.034(0.853)$ & 1 \\
\hline & JX & 13 & 17 & $0.533(0.465)$ & 0.585 & 13 & 17 & $0.533(0.465)$ & 0.585 \\
\hline & ZJ & 17 & 11 & $1.286(0.257)$ & 0.345 & 16 & 11 & $0.926(0.336)$ & 0.442 \\
\hline & $\mathrm{HN}$ & 14 & 16 & $0.133(0.715)$ & 0.856 & 14 & 15 & $0.034(0.853)$ & 1 \\
\hline & Total & 70 & 72 & $0.028(0.867)$ & 0.933 & 69 & 70 & $0.007(0.932)$ & 1 \\
\hline \multirow{5}{*}{ Orchard } & O1 & 9 & 16 & $1.960(0.162)$ & 0.23 & 8 & 15 & $2.130(0.144)$ & 0.21 \\
\hline & $\mathrm{O} 2$ & 14 & 10 & $0.667(0.414)$ & 0.541 & 13 & 10 & $0.391(0.532)$ & 0.678 \\
\hline & $\mathrm{O} 3$ & 12 & 16 & $0.571(0.450)$ & 0.572 & 12 & 16 & $0.571(0.450)$ & 0.572 \\
\hline & $\mathrm{O} 4$ & 9 & 16 & $1.960(0.162)$ & 0.23 & 9 & 16 & $1.960(0.162)$ & 0.23 \\
\hline & Total & 44 & 58 & $1.992(0.166)$ & 0.198 & 42 & 57 & $2.273(0.132)$ & 0.159 \\
\hline \multirow{6}{*}{ Tree } & $\mathrm{T} 1$ & 7 & 9 & $0.250(0.617)$ & 1 & 6 & 4 & $0.40(0.527)$ & 0.754 \\
\hline & $\mathrm{T} 2$ & 6 & 11 & $1.471(0.225)$ & 0.332 & 6 & 11 & $1.471(0.225)$ & 0.332 \\
\hline & T3 & 10 & 14 & $0.667(0.414)$ & 0.541 & 10 & 14 & $0.667(0.414)$ & 0.541 \\
\hline & $\mathrm{T} 4$ & 12 & 6 & $2.000(0.157)$ & 0.238 & 11 & 5 & $2.25(0.134)$ & 0.21 \\
\hline & T5 & 12 & 8 & $0.8(0.371)$ & 0.503 & 12 & 8 & $0.8(0.371)$ & 0.503 \\
\hline & Total & 47 & 48 & $0.011(0.918)$ & 1 & 45 & 42 & $0.103(0.748)$ & 0.83 \\
\hline
\end{tabular}

a The $p$ values in parentheses indicate if the ratio was significantly different to 1:1 (significant if $p \leq 0.05$ ), calculated in IBM SPSS Statistics 20 (International Business Machines Corporation, Armonk, NY, USA). ${ }^{b}$ Probability from a two-tailed exact binomial analysis to test whether MAT frequencies deviate significantly from a 1:1 ratio, calculated in IBM SPSS Statistics 20 (International Business Machines Corporation, Armonk, NY, USA).

\subsection{Linkage Disequilibrium and Recombination}

For the original non-clone-corrected data, most (16/21) of the subpopulations did not reject the null hypothesis of linkage equilibrium $(p>0.05)$, except for five subpopulations: GZ $(p=0.001), \mathrm{ZJ}(p=0.001), \mathrm{O} 2(p=0.012), \mathrm{T} 1(p=0.001)$, and T5 $(p=0.015)$. Similarly, Prp values were consistent with phylogenetic incompatibility in most of the subpopulations $(p>0.05)$, except for FJ $(p=0.020), \mathrm{GZ}(p=0.025), \mathrm{ZJ}(p=0.001), \mathrm{T} 1(p=0.010)$, $\mathrm{T} 4(p=0.001)$, and T5 $(p=0.043)$. In the clone-corrected data, the T1 subpopulation was in linkage equilibrium $(p=0.126)$, with a Prp value of 0.807 . For both the non-clone-corrected and clone-corrected data, phylogenetic incompatibility was found in all subpopulations (Table 7). These results provided strong evidence that $D$. citri underwent sexual reproduction in these natural populations. However, the weak but statistically significant linkage disequilibrium observed in some subpopulations also suggests evidence of genetic linkage and clonal reproduction. 
Table 7. Linkage disequilibrium and recombination analyses for Diaporthe citri populations from different scales in China ${ }^{1}$.

\begin{tabular}{|c|c|c|c|c|c|c|c|c|c|c|c|c|c|}
\hline \multirow{2}{*}{ Scale } & \multirow{2}{*}{ Subpopulation } & \multicolumn{6}{|c|}{ Raw Data } & \multicolumn{6}{|c|}{ Clone-Corrected Data } \\
\hline & & $\mathbf{N}$ & $\mathbf{I}_{\mathbf{A}}$ & $\overline{\mathbf{r}}_{\mathbf{d}}$ & $p^{2}$ & Prp & $p^{3}$ & $\mathbf{N}$ & $\mathbf{I}_{\mathbf{A}}$ & $\overline{\mathbf{r}}_{\mathbf{d}}$ & $p$ & Prp & $p$ \\
\hline \multirow{6}{*}{ Province } & FJ & 24 & 0.098 & 0.008 & 0.171 & 0.044 & 0.020 & 24 & 0.098 & 0.008 & 0.144 & 0.044 & 0.020 \\
\hline & GZ & 30 & 0.531 & 0.050 & 0.001 & 0.484 & 0.025 & 29 & 0.484 & 0.045 & 0.003 & 0.484 & 0.025 \\
\hline & $\mathrm{JX}$ & 30 & 0.024 & 0.002 & 0.383 & 0.527 & 0.735 & 30 & 0.024 & 0.002 & 0.371 & 0.527 & 0.735 \\
\hline & $\mathrm{ZJ}$ & 28 & 2.322 & 0.195 & 0.001 & 0.396 & $<0.001$ & 27 & 2.201 & 0.185 & 0.001 & 0.396 & $<0.001$ \\
\hline & $\mathrm{HN}$ & 30 & 0.123 & 0.013 & 0.125 & 0.626 & 0.544 & 29 & 0.074 & 0.008 & 0.238 & 0.626 & 0.514 \\
\hline & Total & 142 & 2.115 & 0.166 & 0.001 & 0.000 & 1.000 & 139 & 2.091 & 0.164 & 0.001 & 0.000 & 1.000 \\
\hline \multirow{5}{*}{ Orchard } & O1 & 25 & 0.070 & -0.007 & 0.682 & 0.648 & 0.510 & 23 & -0.142 & -0.013 & 0.830 & 0.648 & 0.769 \\
\hline & $\mathrm{O} 2$ & 24 & 0.332 & 0.034 & 0.012 & 0.725 & 0.840 & 23 & 0.259 & 0.027 & 0.043 & 0.725 & 0.822 \\
\hline & $\mathrm{O} 3$ & 28 & 0.104 & 0.010 & 0.219 & 0.615 & 0.709 & 28 & 0.104 & 0.010 & 0.219 & 0.615 & 0.709 \\
\hline & $\mathrm{O} 4$ & 25 & 0.167 & 0.018 & 0.151 & 0.736 & 0.415 & 25 & 0.167 & 0.018 & 0.151 & 0.736 & 0.415 \\
\hline & Total & 102 & 0.120 & 0.011 & 0.030 & 0.330 & 0.794 & 99 & 0.113 & 0.010 & 0.041 & 0.330 & 0.766 \\
\hline \multirow{6}{*}{ Tree } & $\mathrm{T} 1$ & 16 & 1.550 & 0.198 & 0.001 & 0.923 & 0.010 & 10 & 0.319 & 0.041 & 0.126 & 0.923 & 0.807 \\
\hline & $\mathrm{T} 2$ & 17 & 0.072 & 0.007 & 0.293 & 0.670 & 0.280 & 17 & 0.072 & 0.007 & 0.307 & 0.670 & 0.280 \\
\hline & T3 & 24 & 0.137 & 0.013 & 0.156 & 0.593 & 0.595 & 24 & 0.137 & 0.013 & 0.159 & 0.593 & 0.595 \\
\hline & $\mathrm{T} 4$ & 18 & 0.230 & 0.020 & 0.096 & 0.670 & 0.001 & 16 & -0.038 & -0.003 & 0.565 & 0.670 & 0.028 \\
\hline & T5 & 20 & 0.389 & 0.037 & 0.015 & 0.769 & 0.043 & 20 & 0.389 & 0.037 & 0.019 & 0.769 & 0.043 \\
\hline & Total & 95 & 0.158 & 0.014 & 0.014 & 0.275 & 0.514 & 87 & 0.105 & 0.009 & 0.074 & 0.275 & 0.572 \\
\hline
\end{tabular}

${ }^{1} \mathrm{~N}$ : number of isolates; $\mathrm{I}_{\mathrm{A}}$ : index of association; $\overline{\mathrm{r}}_{\mathrm{d}}$ : standard index of association; Prp: Proportion of compatible pairs of loci; ${ }^{2} p$ values of
$\mathrm{I}_{\mathrm{A}}$ and $\overline{\mathrm{r}}_{\mathrm{d}}$, calculated in package poppr with 999 permutations; ${ }^{3} p$ values of Prp, calculated in Multilocus $1.3 \mathrm{~b}$ with 1000 permutations.

\subsection{Genetic Diversity of the Two MAT Idiomorph Populations}

Allele diversity analyses, including the number of different alleles, the number of effective alleles, Shannon's information indices, Nei's gene diversities, and unbiased allelic diversities between the MAT1-1 and MAT1-2 subpopulations, showed high and similar levels of genetic diversity at all three spatial levels (Table 8). For both the non-clone-corrected and clone-corrected dataset, AMOVA showed that less than $1 \%$ of the genetic variation could be explained by differences between the MAT1-1 and MAT1-2 subpopulations at all three spatial scales (Figure 8). Furthermore, the minimum spanning network revealed that the MLGs of two mating types were intermixed at all three of the studied scales (Figure 9). Together, these results are consistent with frequent mating and recombination in natural populations of $D$. citri in citrus orchards.

Table 8. Allele diversity of two mating type-based subpopulations at three different spatial scales ${ }^{1}$.

\begin{tabular}{|c|c|c|c|c|c|c|c|c|}
\hline Scale & Pops & Subpops & $\mathbf{N}$ & $\mathbf{N a}$ & $\mathrm{Ne}$ & I & h & uh \\
\hline \multirow{12}{*}{ Province } & \multirow{2}{*}{$\mathrm{FJ}$} & MAT1-1 & 11 & 4.143 & 3.031 & 1.142 & 0.600 & 0.660 \\
\hline & & MAT1-2 & 13 & 4.286 & 3.077 & 1.187 & 0.628 & 0.680 \\
\hline & \multirow{2}{*}{ GZ } & MAT1-1 & 15 & 3.214 & 2.231 & 0.768 & 0.408 & 0.437 \\
\hline & & MAT1-2 & 14 & 2.786 & 2.081 & 0.666 & 0.370 & 0.398 \\
\hline & \multirow{2}{*}{$\mathrm{JX}$} & MAT1-1 & 13 & 2.214 & 1.784 & 0.535 & 0.313 & 0.339 \\
\hline & & MAT1-2 & 17 & 2.357 & 1.810 & 0.592 & 0.356 & 0.379 \\
\hline & \multirow{2}{*}{ ZJ } & MAT1-1 & 16 & 4.357 & 3.033 & 1.153 & 0.597 & 0.637 \\
\hline & & MAT1-2 & 11 & 3.357 & 2.198 & 0.842 & 0.451 & 0.496 \\
\hline & \multirow{2}{*}{$\mathrm{HN}$} & MAT1-1 & 14 & 2.786 & 2.080 & 0.659 & 0.355 & 0.382 \\
\hline & & MAT1-2 & 15 & 2.929 & 2.078 & 0.693 & 0.374 & 0.401 \\
\hline & \multirow{2}{*}{ Total } & MAT1-1 & 69 & 7.571 & 3.502 & 1.405 & 0.645 & 0.654 \\
\hline & & MAT1-2 & 70 & 8.071 & 3.716 & 1.428 & 0.648 & 0.658 \\
\hline
\end{tabular}


Table 8. Cont.

\begin{tabular}{|c|c|c|c|c|c|c|c|c|}
\hline Scale & Pops & Subpops & $\mathbf{N}$ & $\mathrm{Na}$ & $\mathrm{Ne}$ & I & h & uh \\
\hline \multirow{10}{*}{ Orchard } & \multirow{2}{*}{ O1 } & MAT1-1 & 8 & 2.286 & 1.781 & 0.576 & 0.342 & 0.390 \\
\hline & & MAT1-2 & 15 & 3.214 & 2.077 & 0.722 & 0.377 & 0.404 \\
\hline & \multirow[b]{2}{*}{$\mathrm{O} 2$} & MAT1-1 & 13 & 2.714 & 1.889 & 0.576 & 0.298 & 0.323 \\
\hline & & MAT1-2 & 10 & 2.643 & 1.872 & 0.649 & 0.370 & 0.411 \\
\hline & \multirow{2}{*}{$\mathrm{O} 3$} & MAT1-1 & 12 & 2.929 & 1.912 & 0.681 & 0.369 & 0.403 \\
\hline & & MAT1-2 & 16 & 2.929 & 2.007 & 0.645 & 0.338 & 0.361 \\
\hline & \multirow{2}{*}{$\mathrm{O} 4$} & MAT1-1 & 9 & 2.071 & 1.701 & 0.478 & 0.280 & 0.315 \\
\hline & & MAT1-2 & 15 & 2.929 & 1.709 & 0.599 & 0.310 & 0.332 \\
\hline & \multirow[b]{2}{*}{ Total } & MAT1-1 & 42 & 4.429 & 2.204 & 0.801 & 0.398 & 0.408 \\
\hline & & MAT1-2 & 57 & 4.357 & 2.136 & 0.780 & 0.385 & 0.392 \\
\hline \multirow{12}{*}{ Tree } & \multirow[t]{2}{*}{$\mathrm{T} 1$} & MAT1-1 & 6 & 2.000 & 1.659 & 0.454 & 0.266 & 0.319 \\
\hline & & MAT1-2 & 4 & 1.929 & 1.743 & 0.482 & 0.295 & 0.393 \\
\hline & \multirow[t]{2}{*}{$\mathrm{T} 2$} & MAT1-1 & 6 & 2.429 & 2.139 & 0.644 & 0.365 & 0.438 \\
\hline & & MAT1-2 & 11 & 2.571 & 1.937 & 0.624 & 0.351 & 0.386 \\
\hline & \multirow[t]{2}{*}{$\mathrm{T} 3$} & MAT1-1 & 10 & 2.357 & 1.940 & 0.603 & 0.347 & 0.386 \\
\hline & & MAT1-2 & 14 & 2.786 & 2.039 & 0.654 & 0.355 & 0.382 \\
\hline & \multirow[t]{2}{*}{$\mathrm{T} 4$} & MAT1-1 & 11 & 2.929 & 2.276 & 0.756 & 0.410 & 0.451 \\
\hline & & MAT1-2 & 5 & 2.143 & 1.970 & 0.568 & 0.337 & 0.421 \\
\hline & \multirow[t]{2}{*}{$\mathrm{T} 5$} & MAT1-1 & 12 & 2.571 & 1.954 & 0.632 & 0.357 & 0.390 \\
\hline & & MAT1-2 & 8 & 2.071 & 1.602 & 0.448 & 0.254 & 0.291 \\
\hline & \multirow{2}{*}{ Total } & MAT1-1 & 45 & 4.000 & 2.192 & 0.790 & 0.397 & 0.406 \\
\hline & & MAT1-2 & 42 & 3.786 & 2.116 & 0.725 & 0.361 & 0.370 \\
\hline
\end{tabular}

${ }^{1}$ Data were clone-corrected. N, Number of isolates; $\mathrm{Na}$, Number of different alleles; $\mathrm{Ne}$, Number of effective alleles; I, Shannon's information index; H, Nei's gene diversity (Nei, 1973) across all loci; uH, Nei's unbiased genotypic diversity. $\mathrm{Na}, \mathrm{Ne}, \mathrm{I}, \mathrm{H}$, and $\mathrm{uH}$ were calculated in GenAlEx version 6.502.
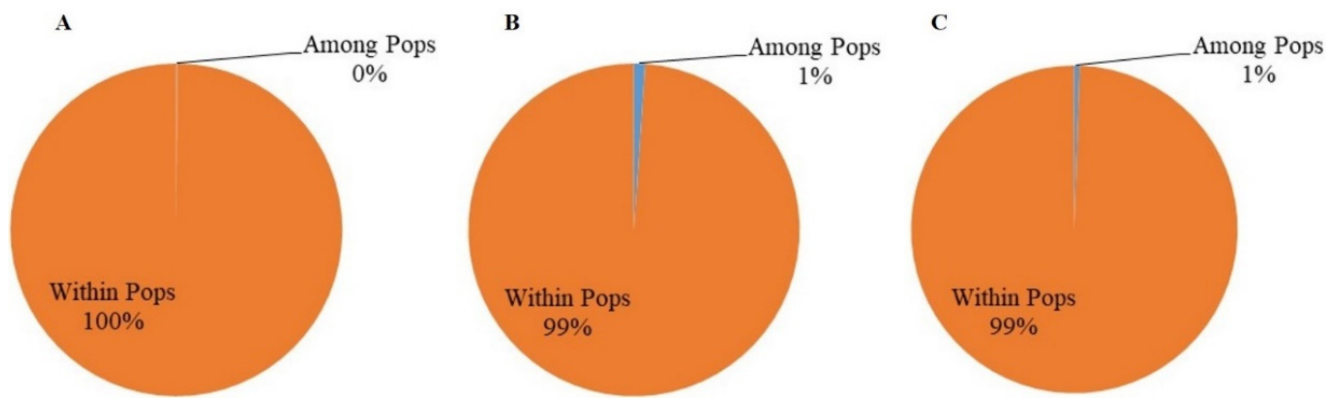

Figure 8. Analysis of molecular variance between the MAT1-1 and MAT1-2 subpopulations of Diaporthe citri at three spatial scales of provincial (A), orchard (B), and tree levels (C). 


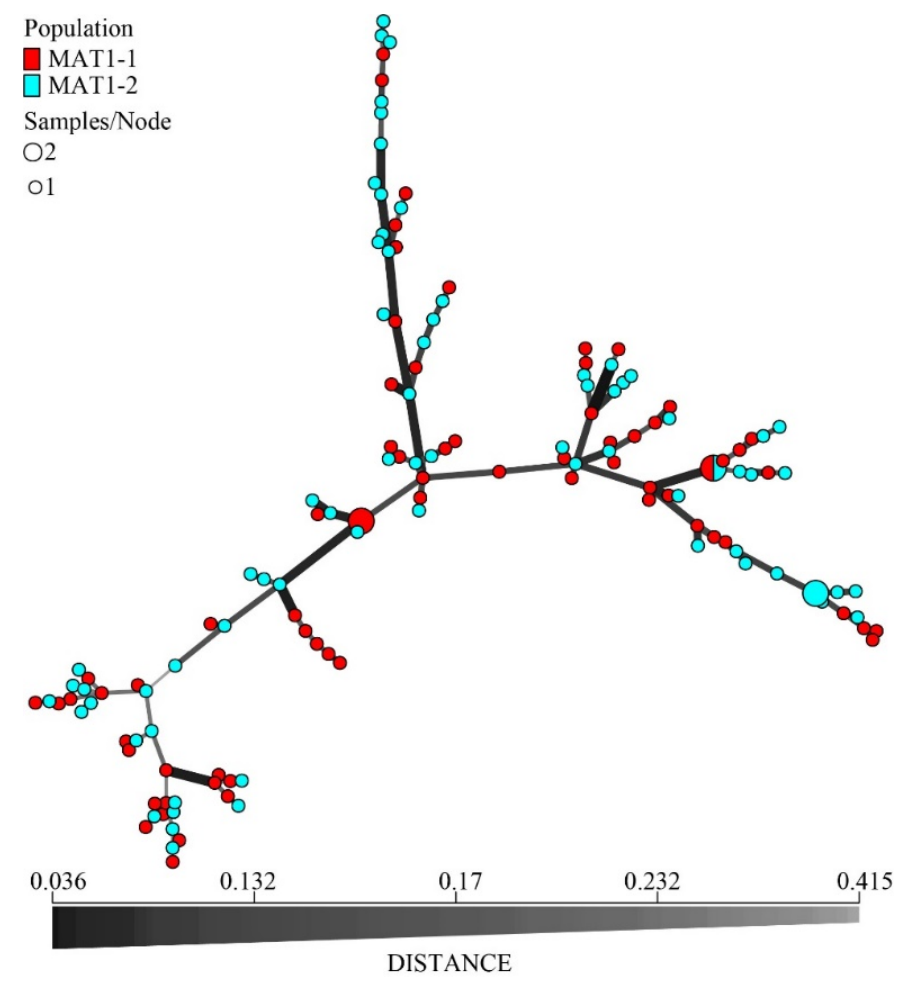

Figure 9. Minimum spanning network based on pairwise Bruvo's genetic distances for isolates belonging to the two mating types at the provincial level. Node size indicates the number of strains of the specific MLG and the branch lengths indicate genetic distance between isolates.

\section{Discussion}

Melanose caused by D. citri is an important disease of citrus in southern China and has significantly influenced the marketability of citrus fruits [3]. In this study, we analyzed the patterns of genetic variation of $D$. citri in orchards of $C$. reticulata and $C$. sinensis to understand the mode of reproduction of D. citri in nature and to reveal the relationships among populations of $D$. citri from different trees, orchards, and provinces in southern China. Consistent with what we hypothesized, geographic separation was found to have played a significant role in structuring the genetic diversity of $D$. citri in southern China. In addition, as was hypothesized, limited differences were found between host tree species-based subpopulations and between plant organ-based subpopulations. However, different from what we expected, both linkage disequilibrium analysis and phylogenetic incompatibility tests revealed abundant evidence for recombination within individual subpopulations. Furthermore, the ratios of the two mating types MAT1-1-1 and MAT1-2-1 in both the total sample and in most subpopulations of D. citri analyzed here did not deviate significantly from 1:1. Together, the genetic signatures of the $D$. citri populations in southern China are consistent with this pathogen being highly endemic in these regions $[19,41]$.

Our analyses revealed that geographical isolation played a significant role in population differentiations among the five provincial populations of $D$. citri. The influences of geography on population structure have been reported in many other plant fungal pathogens such as the wheat pathogen Mycosphaerella graminicola [42], the chili pepper anthracnose pathogen Colletotrichum truncatum [43], the grapevine dieback pathogen Diaporthe spp. [15], the yam wilt pathogen Fusarium oxysporum species complex [44], and the tea-oil tree anthracnose pathogen Colletotrichum fructicola [45]. Indeed, in southern China, a diversity of genetic relationships among regional populations has been observed for plant fungal pathogens, e.g., [43-45]. For example, multilocus sequence typing revealed significant genetic differentiations among regional populations of $C$. fructicola from tea-oil tree plantations in Hunan and Jiangxi provinces [45]. However, long-distance dispersals 
were also found, likely related to tea-oil tree seedling trade among regions by humans [45]. Long-distance sharing of multilocus genotypes has also been reported for other fungi in southern China, including the human fungal pathogens Cryptococcus neoformans [46] and Candida tropicalis [47], likely due to anthropogenic influences on these fungal pathogens. However, different from most previous studies, no shared multilocus genotype was found in this study among isolates of $D$. citri from the five provinces in southern China. The result suggested one of two possibilities. In the first, long-distance dispersal of asexual spores of $D$. citri was uncommon. In the second, long-distance dispersal was common but after dispersal, sexual mating and recombination were frequent enough to break the allelic associations in these asexual propagules to generate new genotypes. Based on the observed allelic distributions among geographic populations at most loci, it seemed that the second possibility was more likely than the first. However, with increased trade and human travel among these provinces, we will likely observe long-distance dispersals of $D$. citri among geographic populations.

We found that the two mating types (MAT1-1-1 and MAT1-2-1) were distributed at similar frequencies in most subpopulations of $D$. citri at all three spatial scales. In combination with results from linkage equilibrium and Prp analyses, this result is consistent with the frequent mating and recombination of $D$. citri in nature. Similar results have been reported in several plant fungal pathogens such as Phyllosticta citricarpa [48,49], Zymoseptoria tritici [50], Dothistroma septosporum [51], and C. truncatum [43]. High genetic diversity is typical of sexually reproducing species [18,20,41]. Carstens et al. [49] studied the global genetic diversity of P. citricarpa, the causal agent of citrus black spot, and found that the populations from China and Australia were sexually reproducing populations with very high genetic diversity. In contrast, the population from United States was consistent with asexual reproduction, with only one multilocus genotype (MLG), and all strains had the same mating type, MAT1-2-1. Our research showed that $D$. citri populations have high levels of genetic diversity at all three studied spatial scales in China, likely due to frequent sexual recombination in orchards. Similar results have been reported another citrus fungal pathogen P. citriasiana [52].

Interestingly, we observed very few shared MLGs among the 339 isolates. Previous studies have suggested that the large number of conidia of $D$. citri produced on dead twigs are likely the infectious propagules that are transmitted to healthy fruits and leaves through rain or irrigation water to cause new infections [53]. If this hypothesis were true, we should observe frequent MLG sharing throughout the same tree and the same orchard. However, our study found very few shared MLGs of D. citri, even in a very small spatial area. Therefore, we speculate that although $D$. citri can produce a large number of conidia in the orchard, the infection rate on citrus by conidia is likely low, with most of the lesions not caused by conidia but likely by sexual spores (ascospores).

A previous study suggested that $D$. citri likely has multiple modes of nutrient acquisition, as a biotroph that can cause diseases, a saprophyte that grows on a variety of dead branches and twigs, and as endophyte living under the epidermis in the intercellular space of trees $[2,7,8]$. As most citrus trees are perennial plants, the D. citri populations could have existed in these orchards for an extended time and represented populations in relative equilibrium. In such equilibrium populations, sexual reproduction and local adaptation are likely common for populations of $D$. citri, potentially making it difficult for immigrants to establish in the endemic niches. However, the observation of significant genetic differentiations among the five provincial populations does not mean that there was no migration. As shown in the minimum spanning tree, closely related strains were found from several geographically distinct areas. In addition, STRUCTURE analyses identified evidence for genetic admixture between the two highly differentiated genetic clusters in most geographic populations (but most prevalent in Zhejiang Province). Together, these results suggest that the $D$. citri populations are likely changing. With increasing human influences, both directly through the exchange of citrus seedlings and indirectly by impacting climate change, the changes in $D$. citri populations will likely accelerate. 
Though the sample size was relatively large, our study only analyzed samples of $D$. citri from two Citrus tree species in 21 orchards in five provinces in southern China. Many issues about the ecology, evolution, and population genetics remain unanswered. For example, at present, the exact host range of $D$. citri outside citrus trees remains undefined. Further sampling and analyses of D. citri populations from host plants outside of Citrus species, from other Citrus species (i.e., species other than C. reticulata and C. sinensis that we analyzed here), and from decaying twigs on the ground over time are needed in order to provide a more robust understanding on the origins and epidemiology of the $D$. citri populations causing citrus melanose.

Author Contributions: Conceptualization, H.L. and J.X.; methodology, T.X.; software, T.X.; formal analysis, T.X. and J.X.; investigation, T.X., Y.Z., W.W., P.L., Y.G., C.J., Z.Z., J.X. and H.L.; writingoriginal draft preparation, T.X.; writing-review and editing, J.X. and H.L.; visualization, T.X.; supervision, H.L. and J.X.; funding acquisition, H.L. All authors have read and agreed to the published version of the manuscript.

Funding: This study was supported by the Key R\&D Program of Zhejiang Province (2019002022), the National Key R\&D Program of China (2017YFD0202000), and China Agriculture Research System (CARS-26).

Institutional Review Board Statement: Not applicable.

Informed Consent Statement: Not applicable.

Data Availability Statement: Not applicable.

Acknowledgments: We thank Ziqing Bai (Guizhou), Liangang Wu (Fujian), Zhongdong Hu (Jiangxi), Jimiao Peng (Hunan), Zhenghua Tang (Hunan), Zhanxu Pu (Zhejiang), and Qun Wu (Zhejiang) for their help during the sample collections.

Conflicts of Interest: The authors declare no conflict of interest.

\section{References}

1. Chaisiri, C.; Liu, X.Y.; Lin, Y.; Li, J.B.; Xiong, B.; Luo, C.X. Phylogenetic analysis development of molecular tool for detection of Diaporthe citri causing melanose disease of citrus. Plants 2020, 9, 329. [CrossRef]

2. Huang, F.; Hou, X.; Dewdney, M.M.; Fu, Y.; Chen, G.; Hyde, K.D.; Li, H.Y. Diaporthe species occurring on citrus in China. Fungal Divers. 2013, 61, 237-250. [CrossRef]

3. Jiang, L.Y.; Xu, F.S.; Huang, Z.D.; Huang, F.; Chen, G.Q.; Li, H.Y. Occurrence control of citrus melanose caused by Diaporthe citri. Acta Agric. Zhejiangensis 2012, 24, 647-653. (In Chinese)

4. Liu, X.; Wang, M.S.; Mei, X.F.; Jiang, L.Y.; Han, G.X.; Li, H.Y. Sensitivity evaluation of Diaporthe citri populations to mancozeb screening of alternative fungicides for citrus melanose control. J. Plant Prot. 2018, 45, 373-381. (In Chinese)

5. Timmer, L.W.; Garnsey, S.M.; Graham, J.H. Compendium of Citrus Diseases, 2nd ed.; American Phytopathological Society Press: St. Paul, MN, USA, 2000.

6. Guarnaccia, V.; Crous, P.W. Emerging citrus diseases in Europe caused by species of Diaporthe. IMA Fungus 2017, 8, 317-334. [CrossRef]

7. Mondal, S.N.; Agostini, J.P.; Zhang, L.; Timmer, L.W. Factors affecting pycnidium production of Diaporthe citri on detached citrus twigs. Plant Dis. 2004, 88, 379-382. [CrossRef] [PubMed]

8. Mondal, S.N.; Vicent, A.; Reis, R.F.; Timmer, L.W. Saprophytic colonization of citrus twigs by Diaporthe citri factors affecting pycnidial production conidial survival. Plant Dis. 2007, 91, 387-392. [CrossRef]

9. Wolf, F.A. The perfect stage of the fungus which causes melanose of citrus. Agric. Res. 1926, 33, 621-625.

10. Udayanga, D.; Castlebury, L.A.; Rossman, A.Y.; Hyde, K.D. Species limits in Diaporthe: Molecular re-assessment of D. citri, D. cytosporella, D. foeniculina, and D. rudis. Persoonia 2014, 32, 83-101. [CrossRef]

11. Udayanga, D.; Castlebury, L.A.; Rossman, A.Y.; Chukeatirote, E.; Hyde, K.D. The Diaporthe sojae species complex: Phylogenetic re-assessment of pathogens associated with soybean, cucurbits other field crops. Fungal Biol. 2015, 119, 383-407. [CrossRef]

12. Guarnaccia, V.; Groenewald, J.Z.; Woodhall, J.; Armengol, J.; Cinelli, T.; Eichmeier, A.; Ezra, D.; Fontaine, F.; Gramaje, D.; Gutierrez-Aguirregabiria, A.; et al. Diaporthe diversity pathogenicity revealed from a broad survey of grapevine diseases in Europe. Persoonia 2018, 40, 135-153. [CrossRef]

13. Thompson, S.M.; Tan, Y.P.; Young, A.J.; Neate, S.M.; Aitken, E.A.; Shivas, R.G. Stem cankers on sunflower (Helianthus annuus) in Australia reveal a complex of pathogenic Diaporthe (Phomopsis) species. Persoonia 2011, 27, 80-89. [CrossRef] 
14. Guarnaccia, V.; Vitale, A.; Cirvilleri, G.; Aiello, D.; Aiello, D.; Susca, A.; Epifani, F.; Perrone, G.; Polizzi, G. Characterisation of pathogenicity of fungal species associated with branch cankers stem-end rot of avocado in Italy. Eur. J. Plant Pathol. 2016, 146, 963-976. [CrossRef]

15. Manawasinghe, I.S.; Dissanayake, A.J.; Li, X.; Liu, M.; Wanasinghe, D.N.; Xu, J.; Zhao, W.; Zhang, W.; Zhou, Y.; Hyde, K.D.; et al. High Genetic Diversity and Species Complexity of Diaporthe Associated with Grapevine Dieback in China. Front. Microbiol. 2019, 10, 1936. [CrossRef]

16. Ruocco, M.; Baroncelli, R.; Cacciola, S.O.; Pane, C.; Monti, M.M.; Firrao, G.; Vergara, M.; Magnano di San Lio, G.; Vannacci, G.; Scala, F. Polyketide synthases of Diaporthe helianthi involvement of DhPKS1 in virulence on sunflower. BMC Genom. 2018, 19, 27. [CrossRef] [PubMed]

17. Says-Lesage, V.; Roeckel-Drevet, P.; Viguié, A.; Tourvieille, J.; Nicolas, P.; de Labrouhe, D.T. Molecular variability within Diaporthe/Phomopsis helianthi from France. Phytopathology 2002, 92, 308-313. [CrossRef] [PubMed]

18. Xu, J. Evolutionary Genetics of Fungi; Horizon Scientific Press: Norfolk, UK, 2005.

19. Stukenbrock, E.H.; McDonald, B.A. The origins of plant pathogens in agro-ecosystems. Annu. Rev. Phytopathol. 2008, 46, 75-100. [CrossRef] [PubMed]

20. Croll, D.; McDonald, B.A. The genetic basis of local adaptation for pathogenic fungi in agricultural ecosystems. Mol. Ecol. 2017, 26, 2027-2040. [CrossRef] [PubMed]

21. Kanematsu, S.; Adachi, Y.; Ito, T. Mating-type loci of heterothallic Diaporthe spp.: Homologous genes are present in opposite mating-types. Curr. Genet. 2007, 52, 11-12. [CrossRef]

22. Gai, Y.; Xiong, T.; Xiao, X.; Li, P.; Zeng, Y.; Li, L.; Riely, B.; Li, H. The genome sequence of the citrus melanose pathogen Diaporthe citri and two citrus related Diaporthe species. Phytopathology 2021, 111, 779-783. [CrossRef]

23. You, F.M.; Huo, N.; Gu, Y.Q.; Luo, M.C.; Ma, Y.; Hane, D.; Lazo, G.R.; Dvorak, J.; Anderson, O.D. BatchPrimer3: A high throughput web application for PCR sequencing primer design. BMC Bioinform. 2008, 9, 253. [CrossRef]

24. Zeng, Y.T.; Xiong, T.; Zheng, X.L.; Wang, D.L.; Li, H.Y. Rapid molecular detection of Diaporthe citri, the pathogen of citrus melanose. J. Zhejiang Agric. 2021. in press (In Chinese)

25. Balloux, F.; Lehmann, L.; de Meeûs, T. The population genetics of clonal partially clonal diploids. Genetics 2003, 164, 1635-1644 [CrossRef] [PubMed]

26. Peakall, R.; Smouse, P.E. GenAlEx 6.5: Genetic analysis in Excel. Population genetic software for teaching research-an update. Bioinformatics 2012, 28, 2537-2539. [CrossRef]

27. Shannon, C.E. A mathematical theory of communication. Bell Syst. Tech. J. 2001, 5, 53-55. [CrossRef]

28. Nei, M. Analysis of gene diversity in subdivided populations. Proc. Natl. Acad. Sci. USA 1973, 70, 3321-3323. [CrossRef]

29. Nei, M. Estimation of average heterozygosity genetic distance from a small number of individuals. Genetics 1978, 89, 583-590. [CrossRef]

30. R Core Team. R: A Language Environment for Statistical Computing. Available online: http://www.R-project.org/ (accessed on 1 March 2021).

31. Kamvar, Z.N.; Tabima, J.F.; Grunwald, N.J. Poppr: An R package for genetic analysis of populations with clonal, partially clonal, and/or sexual reproduction. PeerJ 2014, 2, e281. [CrossRef]

32. Meirmans, P.G.; Hedrick, P.W. Assessing population structure: F(st) related measures. Mol. Ecol. Resour. 2011, 11, 5-18. [CrossRef]

33. Bruvo, R.; Michiels, N.K.; D'Souza, T.G.; Schulenburg, H.A. simple method for the calculation of microsatellite genotype distances irrespective of ploidy level. Mol. Ecol. 2004, 13, 2101-2106. [CrossRef]

34. Pritchard, J.K.; Stephens, M.; Donnelly, P. Inference of population structure using multilocus genotype data. Genetics 2000, 155, 945-959. [CrossRef]

35. Evanno, G.; Regnaut, S.; Goudet, J. Detecting the number of clusters of individuals using the software STRUCTURE: A simulation study. Mol. Ecol. 2005, 14, 2611-2620. [CrossRef]

36. Lalitha, S. Primer Premier 5. Biotech Softw. Internet Rep. 2000, 1, 270-272. [CrossRef]

37. Everitt, B.S. The Analysis of Contingency Tables, 2nd ed.; Chapman \& Hall: London, UK, 1992.

38. Smith, J.M.; Smith, N.; O’Rourke, M.; Spratt, B.G. How clonal are bacteria? Proc. Natl. Acad. Sci. USA 1993, 90, 4384-4388. [CrossRef]

39. Agapow, P.M.; Burt, A. Indices of multilocus disequilibrium. Mol. Ecol. Notes 2001, 1, 101-102. [CrossRef]

40. Milgroom, M.G. Recombination the multilocus structure of fungal populations. Annu. Rev. Phytopathol. 1996, 34, 457-477. [CrossRef] [PubMed]

41. Xu, J. Fundamentals of fungal molecular population genetic analyses. Curr. Issues Mol. Biol. 2006, 8, 75-89.

42. Linde, C.C.; Zhan, J.; McDonald, B.A. Population structure of Mycosphaerella graminicola: From lesions to continents. Phytopathology 2002, 92, 946-955. [CrossRef] [PubMed]

43. Diao, Y.Z.; Zhang, C.; Xu, J.; Lin, D.; Liu, L.; Mtung'e, O.G.; Liu, X.L. Genetic differentiation and recombination among geographic populations of the fungal pathogen Colletotrichum truncatum from chili peppers in China. Evol. Appl. 2015, 8, 108-118. [CrossRef] [PubMed]

44. Fang, D.Z.; Liu, X.L.; Chen, X.R.; Yan, W.W.; He, Y.L.; Cheng, Y.; Chen, J.; Li, Z.M.; Guo, L.T.; Wang, T.H.; et al. Fusarium Species and Fusarium oxysporum Species Complex Genotypes Associated with Yam Wilt in South-Central China. Front. Microbiol. 2020, 11, 1964. 
45. Li, H.; Zhou, G.-Y.; Liu, J.-A.; Xu, J. Population genetic analyses of the fungal pathogen Colletotrichum fructicola on tea-oil trees in China. PLoS ONE 2016, 11, e0156841. [CrossRef] [PubMed]

46. Chen, Y.H.; Yu, F.; Bian, Z.Y.; Hong, J.M.; Zhang, N.; Zhong, Q.S.; Hang, Y.P.; Xu, J.; Hu, L.H. Multilocus Sequence Typing Reveals both Shared and Unique Genotypes of Cryptococcus neoformans in Jiangxi Province, China. Sci. Rep. 2018, 8, 1495. [CrossRef] [PubMed]

47. Wu, J.Y.; Zhou, D.Y.; Zhang, Y.; Mi, F.; Xu, J. Analyses of the global multilocus genotypes of the human pathogenic yeast Candida tropicalis. Front. Microbiol. 2019, 10, 900. [CrossRef]

48. Wang, N.Y.; Zhang, K.; Huguet-Tapia, J.C.; Rollins, J.A.; Dewdney, M.M. Mating type simple sequence repeat markers indicate a clonal population of Phyllosticta citricarpa in Florida. Phytopathology 2016, 106, 1300-1310. [CrossRef]

49. Carstens, E.; Linde, C.C.; Slabbert, R.; Miles, A.K.; Donovan, N.J.; Li, H.; Zhang, K.; Dewdney, M.M.; Rollins, J.A.; Glienke, C.; et al. A global perspective on the population structure reproductive system of Phyllosticta citricarpa. Phytopathology 2017, 107, 758-768. [CrossRef]

50. Siah, A.; Bomble, M.; Tisserant, B.; Cadalen, T.; Holvoet, M.; Hilbert, J.L.; Halama, P.; Reignault, P. Genetic structure of Zymoseptoria tritici in Northern France at region, field, plant.; leaf layer scales. Phytopathology 2018, 108, 1114-1123. [CrossRef] [PubMed]

51. Dale, A.L.; Lewis, K.J.; Murray, B.W. Sexual reproduction gene flow in the pine pathogen Dothistroma septosporum in British Columbia. Phytopathology 2011, 101, 68-76. [CrossRef]

52. Zeng, Y.; Xiong, T.; Liu, B.; Carstens, E.; Chen, X.; Xu, J.; Li, H. Genetic diversity population structure of Phyllosticta citriasiana in China. Phytopathology 2021, 111, 850-861. [CrossRef]

53. Gopal, K.; Lakshmi, L.M. Citrus melanose (Diaporthe citri Wolf): A Review. Int. J. Curr. Microbiol. Appl. Sci. $2014,3,123-124$. 